\title{
Federal Review of State Court Decisions of Federal Questions: The Need for Additional Appellate Capacity*
}

\author{
Preble Stolz $\dagger^{\dagger}$
}

\begin{abstract}
Professor Stolz suggests that the proposed National Court of Appeals be given obligatory jurisdiction to review state court judgments in federal question cases. The Article briefly describes the history of federal review of state court judgments and presents statistical data on the present workloads of federal courts. Professor Stolz argues that the creation of effective direct review of state court judgments will allow a reduction in collateral attacks of state criminal convictions, provide flexibility in allocating business between the state and federal courts, and promote a healthier federalism.
\end{abstract}

In response to the increasing problems of the federal courts, scholars and other observers of the judiciary have recently called for revisions in the structure of the federal appellate courts. ${ }^{1}$ Last year the Commission on Revision of the Federal Court Appellate System recommended that Congress establish a National Court of Appeals with jurisdiction to hear cases referred to it by the United States Supreme Court or cases transferred to it from the present courts of appeals. ${ }^{2}$ Included within the group of cases that could be referred by the Supreme Court were appeals from and petitions for certiorari to the state supreme courts. ${ }^{3}$ Under the Commission's proposal the new court

* This Article is based upon a memorandum prepared by the author for the Commission on Revision of the Federal Court Appellate System in January, 1975. The enterprise started as a joint one with Professor Paul Mishkin and the analysis has throughout benefited from his help as well as from the staff of the Commission. The author wishes to acknowledge the assistance of Charles F. Gorder, Jr. in revising the memorandum for publication.

$\dagger$ Professor of Law, School of Law (Boalt Hall), University of California, Berkeley.

1. See, e.g., Commission on Revision of the Federal Court Appellate System, Structure and Internal Procedures: ReCommendations for Change (1975) [hereinafter cited as The CoMmission Report]; Federal Judicial CenNTER, Report of the Study Group on the Caseload of the Supreme Court (1972) [hereinafter cited as THE FREUND REPORT]. Much of the pressure for these reforms derives from the Supreme Court's increasing inability to provide adequate guidance to the overburdened courts of appeals. See, e.g., THE Commission RePorT, supra at 7-14.

2. The COMmission Report, supra note 1, at 32-38.

3. Id. at 32 . 
would be required to hear state appeals and render decisions on the merits, but the Supreme Court could authorize the new court to dismiss petitions for certiorari to the state courts, ${ }^{4}$ thus terminating the litigation.

This Article assumes that reform will include the creation of a new National Court of Appeals, below the Supreme Court but above the present circuit courts of appeals. ${ }^{5}$ Unlike the Commission, however, this Article argues that the new court's jurisdiction with respect to state courts should be similar to the present jurisdiction of the $\mathrm{Su}$ preme Court. Its authority to review state court decisions would be limited to cases involving federal questions and would extend only to those decisions that do not rest upon an adequate and independent state ground. ${ }^{6}$ This Article proposes, however, that the new court's jurisdiction differ from that of the Supreme Court in one important respect. It should be obligated to hear all state cases raising a properly presented federal question. ${ }^{7}$ Appeal to the Supreine Court would remain available at that Court's discretion.

The role of state courts has not been extensively noticed in proposals to revise the appellate structure of the federal courts. If a new, national court of appeals is created, however, it would be a mistake not to give that court power to review properly presented federal issues

4. Id. at 32-33.

5. The literature is substantial and growing, much of it stimulated by THe FREUND REPORT, supra note 1 . Some of the articles responsive to that proposal are collected in Note, The National Court of Appeals: A Constitutional "Inferior Court"?, 72 Mrctr. L. REv. 290, 291 n.6 (1973). More recently the Advisory Council for Appellate Justice and a special committee of the A.B.A. have also made proposals. See Warren, Let's Not Weaken the Supreme Court, 60 A.B.A.J. 677 (1974). The creation and work of the Commission on Revision of the Federal Court Appellate System have also provoked interest in these problems. THE Commission REPORT, supra note 1. There is also a very useful symposium on the subject in 59 Cornell L. Rev. 571-657 (1974), with contributions froin Dean Cramton, Professor Rosenberg, Judge Haynsworth, Professor Kurland and Judge Friendly. See also the Irvine Lecture recenlty delivered by former Solicitor General Griswold at Cornell University, Rationing Justice-The Supreme Court's Caseload and What the Courts Do Not Do, 60 Cornell L. Rev. 335 (1975); H. HART \& H. WeChSLER, FEDERAL CourTs 526-73 (2d ed. P. Bator, el al 1973) [hereinafter cited as HART \& WECHSLER 2d].

6. The Freund Commission plan iucluded screening of state court decisions for possible resolution by the Supreme Court, apparently without any other authority to review decisions of the state courts. THE FREUND REPORT, supra note 1 . Judge Haynsworth has proposed a new federal appellate court with jurisdiction over both federal and state criminal cases. Haynsworth, $A$ New Court to Improve the Administration of Justice, 59 A.B.A.J. (1975). The Rosenberg-Carrington plan also calls for a "searching" review of state criminal convictions and, apparently, a recommendation as to certiorari by a proposed Central Division of the Court of Appeals. See Rosenberg, Planned Flexibility to Meet Changing Needs of the Federal Appellate System, 59 Cornell L. Rev. 576 (1974).

7. At present the Supreme Court's jurisdiction is largely discretionary. See 28 U.S.C. $\$ 1257$ (1970). 
in the decisions of state courts. Failure to do so would perpetuate the rigidity and wastefulness of the present system of post-conviction review, reduce the flexibility of the judicial system as a whole to apportion work between the federal and state courts, and needlessly reduce the role of the state courts as adjudicators of federal issues.

\section{CONSTITUTIONALITY}

Before canvassing the inerits of giving an intermediate federal appellate court jurisdiction over the state courts, it should be established that it is constitutionally possible to do so. One possible objection might be based on the phrase in article III that there should be "one supreme Court." The Freund Commission's proposal to create a National Court of Appeals to screen cases for the Supreme Court arguably violates this concept, because in substance the lower court would be able to cut off review of its decisions by the Supreme Court. ${ }^{\circ}$ Thus, because there would be more than one court that could have the final word in certain cases, there would be more than "one supreme Court." Whether the Freund Commission intended this is not altogether clear, ${ }^{10}$ but the problein could be finessed by providing that the Supreme Court could, in its discretion, review the new court's decisions. In any event, as a matter of history the "one supreme Court" argument is of questionable merit smce the first Judiciary Act did not vest appellate jurisdiction in the Supreme Court over all cases that could be heard by the federal courts. ${ }^{11}$

Another objection might be that lower federal courts cannot constitutionally review state court judgments. Congress has never atteinpted to vest a general appellate jurisdiction over the state courts in any court lower than the Supreme Court. ${ }^{12}$ But nothing in article

8. U.S. Const. art. III, $\S \S \mathrm{I}-2$.

9. See Warren, The Proposed New "National Court of Appeals", 28 Recond of N.Y.C.B.A. $627-29$ (1973). The arguments are developed with full citations in Note, The National Court of Appeals: A Constitutional "Inferior Court"?, 72 Micr. L. Rev. 290 (1973).

10. Judge Friendly found the Freund Commission Report ambiguous on this point. H. Friendly, Federal Jurisdiction: A General ViEW 49 (1973) [hereinafter cited as H. FRIENDLY].

11. The big gaps in the first Judiciary Act were created by (1) the escalating jurisdictional amount for appellate review in the Supreme Court $(\$ 2,000$ in civil actions although the district courts and circuit courts had jurisdiction over cases with a jurisdictional minimum ranging from $\$ 50$ to $\$ 500$ ), Act of Sept. 24,1789 , ch. $20, \S \S 12$, 21-22, 1 Stat. 79-80, 83-84; and (2) the absence of any provision for appeal from federal courts in criminal cases although there was limited review through habeas. Id. at $\S 14,1$ Stat. 82.

12. But see note 22 infra. 
III suggests that Congress could not do so; indeed, the language of that article plainly suggests that Congress could vest appellate jurisdiction in the "inferior" federal courts. ${ }^{13}$ Undoubtedly the Framers did not contemplate a workload that would necessitate the creation of an intermediate appellate court between the state courts and the Supreme Court, but they did contemplate that Congress might use inferior federal courts as appellate tribunals with jurisdiction to review state court decisions on federal questions. Alexander Hamilton suggested that this was perhaps the best alternative open to Congress:

I perceive at present no impediment to the establishment of an appeal from the State courts, to the subordinate national tribunals; and many advantages attending the power of domg it may be imagined. It would diminish the motives to the multiplication of federal courts, and would admit of arrangements calculated to contract the appellate jurisdiction of the Supreme Court. The State tribunals may then be left with a more entire charge of federal causes; and appeals in most cases in which they may be deemed proper, instead of being carried to the Supreme Court, may be made to lie from the State courts to district courts of the union. ${ }^{14}$

Congress did not adopt this suggestion in the first Judiciary Act. Section 25 vested appellate jurisdiction over the state courts only in the Supreme Court. ${ }^{15}$ That power was, of course, challenged in Martin

13. The article provides, in part:

The judicial Power of the United States, shall be vested in one Supreme Court, and in such inferior courts as the Congress may from time to time establish. ...

In all cases affecting Ambassadors, other public Ministers and Consuls, and those in which a State shall be a Party, the supreme Court shall have original Jurisdiction. In all other Cases before mentioned, the supreme Court shall have appellate Jurisdiction, both as to Law and Fact, with such Exceptions and under such Regulations as the Congress shall make.

U.S. CoNST. art. III, \$§ 1-2. See note 14 infra.

14. The Federalist No. 82, at 516 (H. Lodge ed. 1888) (A. Hamilton). Hamilton reasoned that lower federal court review of state court judgments was constitutional:

The plan of the convention, in the first place, authorizes the national legislature "to constitute tribunals inferior to the Supreme Court." It declares in the next place, that "the JUDICIAL POWER of the United States shall be vested in one Supreme Court, and in such inferior courts as Congress shall ordain and establish"; and it then proceeds to enumerate the cases to which this judicial power shall extend. It afterwards divides the jurisdiction of the Supreme Court into original and appellate, but gives no definition of that of the subordinate courts. The ouly outlines described for them are, that they shall be "inferior to the Supreme Court," and that they shall not exceed the specified limits of the federal judiciary. Whether their authority shall be original or appellate, or both, is not declared. All this seems to be left to the discretion of the legId. islature.

15. Act of Sept. 24,1789 , ch. $20, \S 25,1$ Stat. $85-87$. 
v. Hunter's Lessee ${ }^{16}$ by a broad argument that it was inconsistent with the independence of state courts to subject their judgments to appellate review by any federal court, including the Supreme Court. Rejectimg that argument, Justice Story found no limitation (apart from the original jurisdiction of the Supreme Court) on the power of Congress to vest appellate jurisdiction in inferior courts over cases within the constitutional grant of federal jurisdiction. ${ }^{17}$ The first Judiciary Act did contain a mechanism for lower federal court intervention in state court proceedings for which the Constitution did not expressly provide: removal of specified causes before trial in the state courts to an inferior federal court for trial. ${ }^{18}$ Although counsel in Martin v. Hunter's Lessee conceded the validity of removal before trial, ${ }^{18}$ removal is im many ways more violative of the authority of state courts than is appellate review since it deprives the state trial machinery of the power to make initial fact determinations. ${ }^{20}$ Removal to an inferior federal court was nonetheless unchallenged until after the Civil $\mathrm{War}^{21}$ and has remained a part of the federal judicial structure. ${ }^{22}$

16. 14 U.S. (1 Wheat.) 304 (1816).

17. We have already seen that appellate jurisdiction is given by the constitution to the supreme court, in all cases where it has not original jurisdiction; subject, however, to such exceptions and regulations as congress may prescribe. ...

But the exercise of appellate jurisdiction is far from being limited, by the terms of the constitution, to the supreme court. There can be no doubt, that congress may create a succession of inferior tribunals, in each of which it may vest appellate as well as original jurisdiction. The judicial power is delegated by the constitution, in the most general terms, and may, therefore, be exercised by congress, under every variety of form, of appellate or original jurisdiction. ...

As, then, by the terms of the constitution, the appellate jurisdiction is not limited as to the supreme court, and as to this court, it may be exercised in all other cases than those of which it has original cognizance, what is there to restrain its exercise over state tribunals, in the enumerated cases? The appellate power is not limited by the terms of the third article to any particular courts. The words are, "the judicial power (which includes appellate power) shall extend to all cases," \&c., and "in all other cases before inentioned the supreme court shall have appellate jurisdiction." It is the case, then, and not the court, that gives the jurisdiction. If the judicial power extends to the case, it will be in vain to search in the letter of the constitution for any qualification as to the tribunal where it depends." [Einphasis supplied]

Id. at 337-38.

18. See generally HART \& WECHSLER 2d, supra note 5, at 422-23, 1192-94.

19. 14 U.S. (1 Wheat.) at 319-21 (1816).

20. E.g., Tennessee v. Davis, 100 U.S. 257, 295 (1879). As the Court noted in that case, Justice Story treated removal as a form of appellate jurisdiction in Martin v. Hunter's Lessee.

21. Tennessee v. Davis, 100 U.S. 257 (1879).

22. In 1863 Congress provided for renoval in certain cases to a circuit court before or after judgment in a state court with explicit provision for retrial of the facts and law in the circuit court. Act of March 3, 1863, ch. 81, $\$ 5,12$ Stat. 756-57. That was properly held unconstitutional as violating the seventh amendment with respect to facts tried before a state court jury. The Justices v. Murray, 76 U.S. (9 Wall.) 274 (1869). See also HART \& WECHSLER 2d, supra note 5, at 422-23. Although the statute 
Lower federal court review of state court judgments by way of habeas corpus has also come to be accepted as routine. As is true of removal, federal habeas corpus is not, in form, appellate review of state court judgments, but the formal distinction between a prerogative writ and appellate review does not hide the obvious truth that a lower federal court reviews and occasionally reverses the decisions of state supreme courts. ${ }^{23}$ In sum, lower federal courts are authorized by Congress both to sweep cases out of the state system altogether and to reverse decisions finally reached by even the highest court of a state. In this context, a statute authorizing a new intermediate federal appellate court to review state court decisions in which federal issues are properly presented does not seein so to diminish the inherent digmity of the state courts as to be unconstitutional. Judge Friendly has said that the constitutionality of appellate review of state court decisions by inferior federal courts "has never been doubted." ${ }^{24}$ There seems to be no reason to start now.

\section{III}

\section{The Role of State Courts in Federal Question Cases}

It is not easy to review in a few paragraphs the role of state courts as the primary (if not the exclusive) articulators of federal law. ${ }^{25}$ This section attempts such a summary as a predicate for the proposition that the crowded docket of the Supreme Court threatens, if it has not already gravely damaged, the Court's capacity to supervise properly the state courts in their performance of this important federal function. It is perhaps easiest to look at the role of the state courts as enunciators of federal law at three historic points: (1) at the time of the first Judiciary Act; (2) in the post-Civil War period; and (3) over the last decade.

\section{A. The First Judiciary Act}

The Constitution gave Congress discretion not to create any inferior courts, so that the courts of first instance on all federal questions

was also applicable to non-jury cases, the Supreme Court declared it "void" and it apparently was not utilized thereafter.

23. The following statement of the Utah Supreme Court indicates that no one is fooled: "However, permission was given to Mr. Pope to renew his petition in the Federal Court after the Utah Supreme Court lrad made its determination on the matter. In other words, we are given the satisfaction of knowing that that which we do in this matter is of no consequence whatsoever and that the ruling of the Supreme Court of a sovereign stato of the Union is subject to the whim of the inferior courts in the Federal system." Pope v. Turner, 30 Utah 2d 286, 289, 517 P.2d 536, 537 (1973).

24. H. FRIENDLY, supra note 10 , at 11 n.47.

25. HaRT \& Wechsler 2d, supra note 5, at 32-63. See also F. Frankfurter \& J.M. LANDis, The Business of the SUPREMe Court (1927) [hereinafter cited as FRANKFURTER \& LANDIS]. 
(except those within the original jurisdiction of the Supreme Court) would be state courts. The first Congress, however, chose another approach. In the first Judiciary Act it created a system of lower federal courts. Despite that "transcendent achievement," did not grant the federal trial courts jurisdiction in cases "arising under" federal law, and with few exceptions did not make federal trial court jurisdiction exclusive. ${ }^{27}$

Although Congress did not rely exclusively on state courts as the initial expositors of federal law, it created a scheme that contemplated a heavy role for the state courts. Appeal from the state courts to the Supreme Court was by no means generally available. Apart from the physical difficulty of hearing a Massachusetts case in Washington, section 25 of the first Judiciary Act was not a comprehensive grant of appellate jurisdiction in the Supreme Court over all state court cases imvolving federal issues. There was no appeal if the state court judginent was in favor of the claim of a federal right. ${ }^{28}$ The Act reflected primary concern about provincialism in the state courts; hence, it provided for an alternative federal forum for diversity cases, ${ }^{29}$ the right of a nonresident defendant to remove a case from a state to a federal court, ${ }^{30}$ and access to the Supreme Court if the claim of federal right was denied by the state court. ${ }^{31}$ Restricting federal jurisdiction to those instances, however, plainly left an enormous area in which state courts were thought fully competent to articulate federal law.

\section{B. The Post-Civil War Period}

The Civil War brought some changes, as did the Circuit Court of Appeals Act in $1891,{ }^{32}$ but the role of the state courts remained large. In 1875 the state courts lost their nonopoly of federal question cases as a result of a statute giving federal trial courts general federal question jurisdiction, ${ }^{33}$ but the state courts retained coinpetence in such cases since federal question jurisdiction was not made exclusive in the federal courts. The 1875 act vastly enlarged the role of the federal trial courts, which

[c]eased to be restricted tribunals of fair dealing between citizens of different states and became the primary and powerful reliances for

26. FRANKFURTER \& LANDIS, supra note 25 , at 4.

27. Perhaps the most important grant of exclusive jurisdiction was in federal criminal matters. The history and development of the still relatively few grants of exclusive jurisdiction can be found in HART \& WECHSLER 2d, supra note 5, at 418-20.

28. Act of Sept. 24, 1789, ch. 20, § 25, 1 Stat. 85.

29. Act of Sept. 24, 1789, ch. $20, \S 11,1$ Stat. 78.

30. Act of Sept. 24, 1789, ch. 20, § 12, 1 Stat. 79.

31. Act of Sept. 24, 1789, ch. 20, \& 25, 1 Stat. 85 .

32. Act of March 3, 1891, ch. 517, 26 Stat. 826.

33. Act of March 3, 1875, ch. 137, 18 Stat. 470. 
vindicating every right given by the Constitution, the laws, and treaties of the United States. Thereafter, any suit asserting such a right could be begun in the federal courts; any such action begun in the state court could be removed to the federal courts for disposition. ${ }^{34}$

Nevertheless, state court articulation of federal law remained important. The contemporaneous adoption of the fourteenth amendment vastly enlarged the "defensive" use of federal law, particularly against state economic regulatory legislation. Most claims that a state statute violated the fourteenth amendment could be heard only in a state court. The fourteenth amendment's potential for providing minimum procedural guarantees in state criminal cases, although largely undeveloped until recently, was also enforced in the first imstance only by the state courts.

The Supreme Court's jurisdiction over state courts remained substantially unchanged until 1914, when Congress enlarged it by granting the Court discretionary jurisdiction to review state court decisions sustaining a claim of a federal right. ${ }^{35}$ Obligatory jurisdiction over state court judgments denying a claim of a federal right was sharply restricted in $1916^{36}$ —and it remains restricted today, although the Court has made it clear that plenary review is not obligatory. ${ }^{37}$ Discretionary jurisdiction by writ of certiorari over state court judgments in federal question cases, however, remaims unchanged. ${ }^{38}$

\section{The Last Decade}

The statutory structure establishing the Supreme Court's jurisdiction has not changed significantly since the Judges Act of $1925^{30}$ What has changed (and dramatically) is the workload of the judicial system. Table I attempts to gather such figures as are available with respect to the Supreme Court from 1916 through 1972. As might be supposed, the Court has been fairly constant in its production of full opimions. The number of cases coming before the Court was also fairly constant through World War II, but since then the Court's docket has nearly quadrupled. The causes of this increase are, of course, multiple and need not be discussed liere at length. ${ }^{40}$ Much is attributable to

34. FRANKFURTER \& LANDIS, supra note 25 , at 65.

35. The background of the 1914 Act, Act of Dec. 23, 1914, ch. 2, 38 Stat. 790, is discussed in FRANKFURTER \& LANDIS, supra note 25, at 190-98.

36. The Webb Act of 1916, Act of Sept. 6, 1916, ch. 448, 39 Stat. 726, is discussed in FRANKFURTER \& LANDIS, supra note 25, at 210-14.

37. Today there seems to be little difference between the way the Court handles appeals and petitions for certiorari. HART \& WeCHSLER 2d, supra note 5, at 631-62.

38. 28 U.S.C. $\$ 1257$ (1970).

39. Act of Feb. 13, 1925, ch. 229, 43 Stat. 936.

40. See authorities cited note 1 supra. 
Table I

U.S. Supreme Court Workload by Source of CaseFederal or State Court

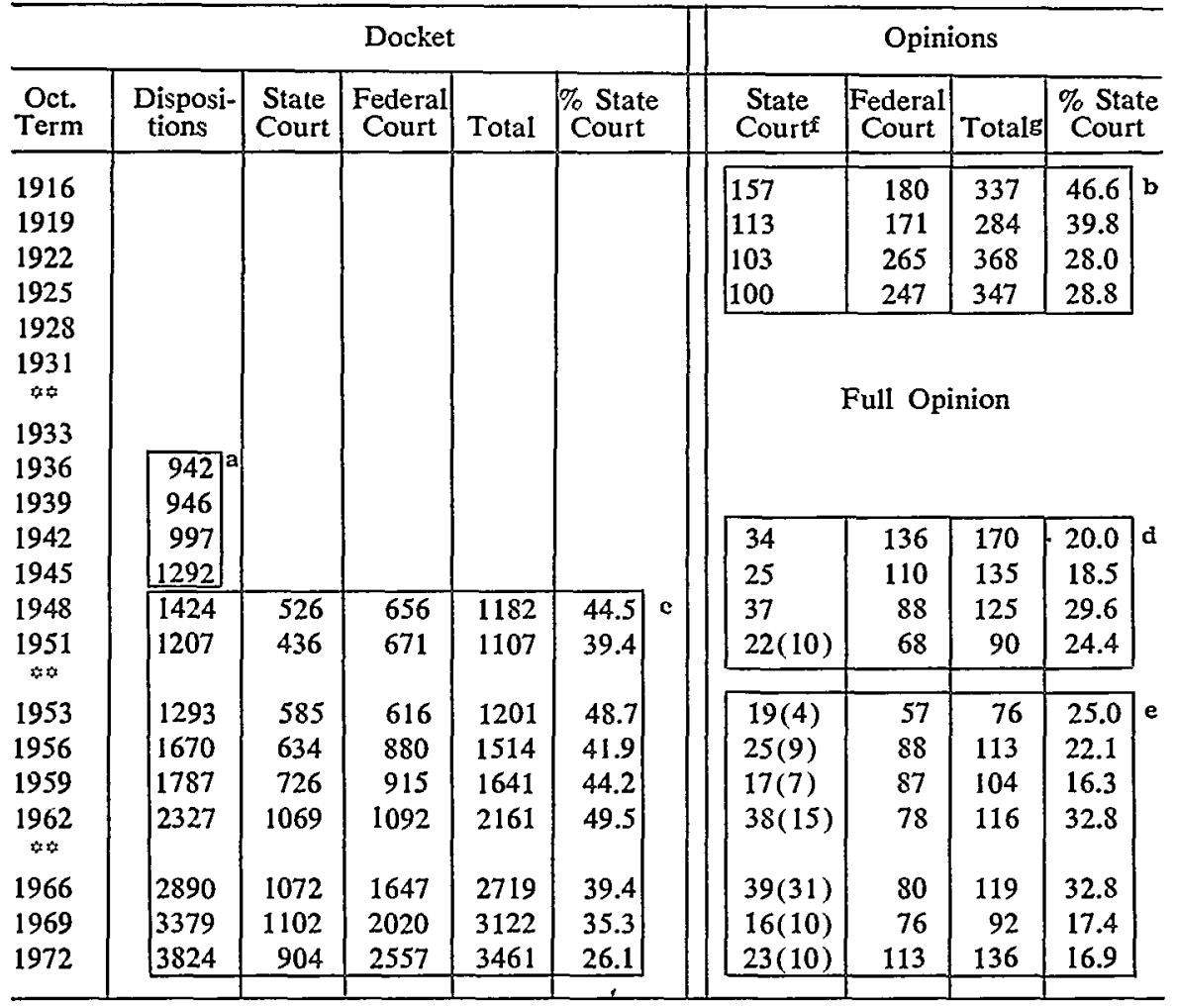

a. This is the only figure available which probably counts the same thing over time. The figures are from Table I of THE FREUND REPORT which gives as the source the Clerk of the Supreme Court. The numbers represent cases finally acted on during the term. For some unexplained reason the figures are not quite identical with those reported by Law Week in its annual statistical review, although Law Week also gives the Clerk's office as its source. The figure for 1972 is compiled from Review of the Supreme Court's Work, 44 U.S.L.W. 3060 (July 29, 1975).

b. These figures are derived from a tablel in FRANKFuRTER AND LANDIs, supra note 16, Table I at 295. They are not directly comparable to the figures below since they include dispositions on the merits without full opinions. They are included here because they are the only available figures on the distribution of the Court's workload in the earlier period based on the court below.

c. These figures come from the Appendix infra. From 1948 to 1962 they are based on the yearly notes "The Supreme Court" of the HaRvard Law REview.

d. These figures come from the statistical summary of the Court's work published in Law Week. Review of Supreme Court's Work, 11 U.S.L.W. 3395, 3396 (June 29, 1943), 14 U.S.L.W. 3443, 3444 (June 18, 1946), 18 U.S.L.W. 3019, 3020 (July 5, 1948). Law Week collected them for the purpose of computing a reversal-affirmance average for the court below. That leads to some double counting where one full opinion disposes of several cases from more than one court. Thus the total number of full opinions is somewhat overstated in contrast to the figures below.

e. These figures are from the annual Supreme Court Note of the Harvaro LAw REVIEw for the years represented. What is a "full" opinion is a somewhat arbitrary classification; it is more than a summary disposition on the merits but it includes per curiam opinions of a few pages.

f. The numbers in parentheses represent the number of criminal cases and are included in the state court total.

g. Excluded are cases on the original docket. 
the provision of counsel at government expense in criminal cases. There also seems to be a general willingness to appeal cases that was unknown before World War II. ${ }^{41}$ Furthermore, there are more people and more complex forms of regulation protective of interests that were less valued earlier, such as civil rights and the environment.

The state court workload has also been mcreasing, although at a less rapid rate than that of the federal courts. Table II presents figures from the California and the federal courts over the last decade. Both systems show a steady growth at the trial court level, but there has been a much faster growth in recent years in the business of the federal district courts. Even more rapid growth has been taking place in the business of the intermediate appellate courts in both systems. The growth rate of the Califormia and federal courts of appeals were roughly parallel for inuch of the decade. In the last few years, however, the dockets of the California courts of appeals seen to have stabilized, whereas those of the federal courts of appeals have continued to grow at a rapid rate. The United States Supreme Court's docket (to be distinguished from its opinions) has grown steadily, but at a rate lower than that of the federal courts of appeals. The Califormia Supreme Court's docket, lowever, peaked in 1969-70 and has been trending downward shightly. It is not known whether the California situation represents the trend in other states ${ }^{42}$ nor whether this decline presages a snmilar slow-down in the federal system.

The inability of the Supreme Court to maintain unifornity among the circuits because of the increase in its workload has been widely noticed in recent years. Obviously, as the universe of cases that might be heard increases while the ability of the Supreme Court to decide cases on the inerits remains constant, the capacity of the Supreme Court to control the lower courts-both state and federal-declines. A similar effect has been observed within the larger circuits. As the caseload and the number of judges increase, the "law of the circuit" becones harder to discern. ${ }^{43}$

41. Carrington, Crowded Dockets and the Courts of Appeal, 82 HARv. L. REv. $542,544-47$ (1969).

42. The decline in the absolute number of cases from state courts on the Supreme Court's docket might suggest that the phenomenon is national. But that is a very hazardous projection. The tables in the Appendix infra, showing the state from which the appeal (or certiorari) was taken, indicate that the problem is inuch inore complex. Litigants in some states seem peculiarly prone to seek Supreme Court review, while litigants in other states seems peculiarly disinterested. This suggests that the Supreme Court's docket is a very unreliable index of the volume of federal business in state courts.

Nonetheless, the steadiness of the California Supreme Court's docket over the last five years, despite the continued growth of the intermediate appellate courts' business, is puzzling and possibly important.

43. Carrington, Crowded Dockets and the Courts of Appeal, 82 HARv. L. REv. $542,580-96$ (1969). 
Table II

Business of the Federal and California Courts 1962-63 through 1973-74*

\begin{tabular}{|c|c|c|c|c|c|c|c|c|}
\hline $\begin{array}{l}\text { Oct. } \\
\text { Term }\end{array}$ & $\begin{array}{l}\text { Fiscal } \\
\text { Year }\end{array}$ & $\begin{array}{c}\text { U.S. } \\
\text { S.Ct. } \\
\text { Disposi- } \\
\text { tionsh }\end{array}$ & $\begin{array}{c}\text { Federal } \\
\text { CA } \\
\text { Termina } \\
\text { tions }\end{array}$ & $\begin{array}{c}\text { U.S. } \\
\text { 9th CA } \\
\text { Termina- } \\
\text { tionsi }\end{array}$ & $\begin{array}{c}\text { Calif. } \\
\text { S. Ct. } \\
\text { Filingsj }\end{array}$ & $\begin{array}{c}\text { Calif. } \\
\text { C.A. } \\
\text { Filingsi }\end{array}$ & $\begin{array}{l}\text { U.S. Dist. } \\
\text { Court } \\
\text { Termina- } \\
\text { tionsi }\end{array}$ & $\begin{array}{c}\text { Calif. } \\
\text { Superior } \\
\text { Ct. } \\
\text { Filingsj }\end{array}$ \\
\hline \multicolumn{2}{|c|}{$1962-63$} & 7 & 5,011 & 587 & $1,562^{* *}$ & 3,295 & 93,925 & 373,190 \\
\hline \multicolumn{2}{|c|}{$1963-64$} & & & & & & & \\
\hline \multicolumn{2}{|c|}{$1964-65$} & & & & $2,569 * *$ & 4,572 & & 338 \\
\hline \multicolumn{2}{|c|}{$1965-66$} & & & & $2,522 * *$ & & & 895 \\
\hline \multicolumn{2}{|c|}{$1966-67$} & & & & & & & \\
\hline \multicolumn{2}{|c|}{$1967-68$} & & & & & & & 560 \\
\hline \multicolumn{2}{|c|}{$1968-69$} & & & 1, & 3 & 6,874 & & 493,631 \\
\hline \multicolumn{2}{|c|}{$1969-70$} & & & & & 8,039 & & 507,163 \\
\hline \multirow{2}{*}{\multicolumn{2}{|c|}{$\begin{array}{l}1970-71 \\
1971-72\end{array}$}} & & & 1,725 & 3,179 & 8,684 & & 527,488 \\
\hline & & & & & & & & 522,256 \\
\hline \multicolumn{2}{|c|}{$1972-73$} & & & & & & & 532,563 \\
\hline \multicolumn{2}{|c|}{$1973-74$} & 3,965 & 15,422 & 2,551 & 3,513 & 9,805 & 139,159 & 562,062 \\
\hline
\end{tabular}

Index of Growth Using 1967-68 as the Base Year

\begin{tabular}{|c|c|c|c|c|c|c|c|c|}
\hline $\begin{array}{l}\text { Oct. } \\
\text { Term }\end{array}$ & $\begin{array}{l}\text { Fiscal } \\
\text { Year }\end{array}$ & $\begin{array}{c}\text { U.S. } \\
\text { S. Ct. } \\
\text { Disposi- } \\
\text { tions }\end{array}$ & $\begin{array}{c}\text { Federal } \\
\text { CA } \\
\text { Termina- } \\
\text { tions }\end{array}$ & $\begin{array}{c}\text { U.S. } \\
\text { 9th CA } \\
\text { Termina- } \\
\text { tions }\end{array}$ & $\begin{array}{l}\text { Calif. } \\
\text { S. Ct. } \\
\text { Filings }\end{array}$ & $\begin{array}{l}\text { Calif. } \\
\text { C.A. } \\
\text { Filings }\end{array}$ & $\begin{array}{l}\text { U.S. Dist. } \\
\text { Court } \\
\text { Termina- } \\
\text { tions }\end{array}$ & $\begin{array}{c}\text { Calif. } \\
\text { Superior } \\
\text { Ct. } \\
\text { Filings }\end{array}$ \\
\hline \multicolumn{2}{|c|}{$1962-63$} & 79 & 61 & 64 & 53 & 51 & 94 & 80 \\
\hline \multicolumn{2}{|c|}{$1963-64$} & 82 & 69 & & 63 & 60 & 95 & 85 \\
\hline \multicolumn{2}{|c|}{$1964-65$} & 74 & 70 & & 87 & 71 & 97 & 89 \\
\hline \multirow{2}{*}{\multicolumn{2}{|c|}{$\begin{array}{l}1965-66 \\
1966-67\end{array}$}} & 90 & 80 & & 85 & 78 & 97 & 93 \\
\hline & & 98 & 91 & & 92 & 86 & 100 & 95 \\
\hline \multicolumn{2}{|c|}{$1967-68$} & 100 & 100 & 100 & 100 & 100 & 100 & 100 \\
\hline \multicolumn{2}{|c|}{$1968-69$} & 106 & 109 & 121 & 112 & 107 & 106 & 106 \\
\hline \multicolumn{2}{|c|}{$1969-70$} & 115 & 129 & 166 & 115 & 125 & 117 & 108 \\
\hline \multicolumn{2}{|c|}{$1970-71$} & 113 & 150 & 188 & 107 & 135 & 126 & 113 \\
\hline \multirow{2}{*}{\multicolumn{2}{|c|}{$\begin{array}{l}1971-72 \\
1972-73\end{array}$}} & 124 & 167 & 214 & 109 & 133 & $143=$ & 112 \\
\hline \multirow{2}{*}{\multicolumn{2}{|c|}{$\begin{array}{l}19 / 2-73 \\
1973-74\end{array}$}} & 130 & 183 & 233 & 106 & 143 & 141 & 114 \\
\hline & & 135 & 187 & 278 & 119 & 153 & 139 & 120 \\
\hline
\end{tabular}

* Notice that the figures for the two court systems are not quite comparable. The figures for the federal courts count dispositions or terminations (file closings). In contrast, the California court figures are for filings and thus represent the opening of a file. The difference should not be material in reflecting relative change over time.

h. These are the number of cases disposed of or terminated during that term of Court as reported by the Clerk of the Supreme Court. See the note to Table III infra. The figures reported here are those from Table I supra.

i. These figures are from the Annual Report of the Administrative Office of the United States Courts. Note that they are reported on a fiscal year basis. See DIRECTOR OF THE ADMINISTRATIVE OFFICE OF THE UNITED STATES COURTS, REPORTS OF the Proceedings of the Judicial Conference of tHe United States 179, 183, 202, 277 (1974); Director of tHe AdMinistrative OfFICE OF THE UNITED STATES CoURTS, REPORTS OF THE PROCEEDINGS OF THE JUDICIAL CONFERENCE .OF THE UNITED STATES 177 (1968); DiRECTOR OF THE ADMINISTRATIVE OFFICE OF THE UNITED-STATES CoURTS, Reports of the Proceedings of the Judicial Conference of the United States 185 (1963).

j. These figures are from the ANNuAd Report of the Administrative OfFice of the California Courts 69, 72, 82 (1975) and ANNUAL REPORT OF tHE ADMINISTRATIVE OfFice of the California Courts 11, 15, 21 (1966).

* The figures for these years inflate somewhat the workload of the California Supreme Court. Before a constitutional amendment in 1966, cases could be appealed directly to the Supreme Court, but that Court routinely transferred all but a few cases for initial appellate consideration by a court of appeals. Cases so transferred nonetheless show up as filings for the California Supreme Court. 
Table III

U.S. Supreme Court Dispositions

\begin{tabular}{|c|c|c|c|c|c|c|}
\hline $\begin{array}{l}\text { Oct. } \\
\text { Term }\end{array}$ & $\begin{array}{l}\text { Fiscal } \\
\text { Year }\end{array}$ & $\begin{array}{c}\text { Supreme } \\
\text { Court } \\
\text { Dispositionsk }\end{array}$ & $\begin{array}{c}\text { Fed. CA } \\
\text { Certiorari } \\
\text { Petitions } \\
\text { Disposed of } 1\end{array}$ & $\begin{array}{l}\text { Non-Fed. } \\
\text { CA Dis- } \\
\text { positions }\end{array}$ & $\begin{array}{l}\% \text { Non } \\
\text { CA Dis- } \\
\text { positions }\end{array}$ & $\begin{array}{c}\text { State } \\
\text { Court } \\
\text { Percentm }\end{array}$ \\
\hline 951 & -52 & 1207 & \multirow[t]{2}{*}{610} & \multirow[t]{2}{*}{597} & \multirow[t]{2}{*}{49.5} & \multirow[t]{2}{*}{39.4} \\
\hline,$\ngtr 52$ & -53 & 1278 & & & & \\
\hline 1553 & -54 & 1293 & \multirow[t]{3}{*}{563} & \multirow[t]{3}{*}{730} & \multirow[t]{3}{*}{56.5} & \multirow[t]{3}{*}{48.7} \\
\hline $\mid \gg 34$ & -55 & 1352 & & & & \\
\hline 1955 & -56 & 1630 & & & & \\
\hline 1956 & -57 & 1670 & \multirow[t]{3}{*}{819} & \multirow[t]{3}{*}{851} & \multirow[t]{3}{*}{51.0} & \multirow[t]{3}{*}{41.9} \\
\hline$\{0,57$ & -58 & 1765 & & & & \\
\hline 1958 & -59 & 1763 & & & & \\
\hline 1959 & -60 & 1787 & \multirow[t]{3}{*}{838} & \multirow[t]{3}{*}{949} & \multirow[t]{3}{*}{53.1} & \multirow[t]{3}{*}{44.2} \\
\hline 1960 & -61 & 1911 & & & & \\
\hline 1961 & -62 & 2142 & & & & \\
\hline 1962 & -63 & 2327 & \multirow[t]{4}{*}{999} & \multirow[t]{4}{*}{1328} & \multirow[t]{4}{*}{57.1} & \multirow[t]{4}{*}{49.5} \\
\hline 1963 & -64 & 2401 & & & & \\
\hline 1964 & -65 & 2173 & & & & \\
\hline 1965 & -66 & 2665 & & & & \\
\hline 1966 & -67 & 2890 & \multirow[t]{3}{*}{1369} & \multirow[t]{3}{*}{1521} & \multirow[t]{3}{*}{52.6} & \multirow[t]{3}{*}{39.4} \\
\hline$: 967$ & -68 & 2946 & & & & \\
\hline Sos & -69 & 3117 & & & & \\
\hline$k=69$ & -70 & 3379 & \multirow[t]{2}{*}{1966} & \multirow[t]{2}{*}{1413} & \multirow[t]{2}{*}{41.8} & \multirow[t]{2}{*}{35.3} \\
\hline $1 \times 70$ & -71 & 3315 & & & & \\
\hline 1971 & -72 & 3651 & 2163 & 1432 & 40.6 & 31.2 \\
\hline 1972 & -73 & 3824 & 2451 & 1370 & 35.8 & 26.1 \\
\hline
\end{tabular}

Gootnotes to Table III

The Supreme Court keeps its records based on the term of Court which starts October 1 and usually ends in June. Cases filed after the conclusion of the term are reported as filed in the October term of that year which may result in some discontinuity with the Adminisi, ative Office which keeps records on a Fiscal year basis, July 1 to June 30 .

k. These are the number of cases disposed of or terminated during that term of Court as reported by the Clerk of the Supreme Court. The figures reported here are those from the sources cited in Table I supra.

1. These are the total of certiorari petitions from the courts of appeals disposed of during the fiscal year (i.e., granted, denied, or dismissed) as reported in Director of THE Administrative OfFice of the United States Courts, Reports of the Proceedings of the Judicial Conference of the Unitei) States, Table B-2, for the cerm cited.

1.. These figures are from the Appendix infra. 
Because this Article deals with the function of state courts as deciders of federal questions, it would be helpful to know whether the number of cases involving federal questions that state courts (at any level) are deciding is imcreasing. Unfortunately, that kind of statistic seems to be unavailable. ${ }^{44}$ One might suppose that inferences could be drawn from shifts in the state court workload of the Supreme Court. But even that statistic has not been officially counted ${ }^{45}$ and has to be painfully reconstructed from published docket entries. Recently PiOfessors Casper and Posner have gone through that sort of process using as their source for analysis the one-paragraph descriptions of cases putlished in Law Week. Law Week, however, covers only the cases in which the filing fee at the Supreme Court was paid; it excludes the in forma pauperis cases. ${ }^{46}$

Table IV uses the data Professors Casper and Posner collected. It sliows that the percentage of state court cases on the paid docket lias increased slightly from 1957 and 1958 to 1971 and 1972, frota roughly 25 percent of the docket to 30 percent. The growth has besa concentrated in the state criminal cases; state civil litigation as a percentage of the paid docket has held steady or declined shightly. In co:trast, the data presented in the Appendix, based on the total doct $6 t$ (both paid and in forma pauperis cases) for four terms, indicate it $; t$. both the absolute number and the percentage of state cases have actually declined. Most of that decline is attributable to a decrease in the

44. State court authorities do not, at either the trial or appellate level, count separately cases in which a federal issue is raised. The range of federal claims that might be asserted in a state court, especially in criminal cases, has undoubtedly increased in the last 10 to 20 years. Of course it does not follow that they are in fact asserted or that a large number survive the appellate process in a form in which the federal issu: is potentially decisive. The number of FELA and Jones Act cases in the state courts are probably stable or dechining since these cases are declining in the federal courts. Administrative Office of the United States Courts, AnNual Report of the Director of the AdMINISTRative OfFice of the United States CourTs 173, at 128. Preemption claims are perhaps more frequent as substantive federal law has grown into areas formerly left solely to state control. The latter may be counterbalanced by increasing assertion of federal rights through declaratory actions in the federal colirts and by the growth of cases under 42 U.S.C. $\$ 1983$ (1970) in the federal district courts.

What does seem certain is that the busmess of the state courts has grown subsiantially, although probably not as rapidly as that of the federal courts. It is also clear inat the heavy volume of litigation remains in the state courts. Each year the superior courts of California (which handle felony cases and civil cases over $\$ 5,000$ ) do three to four times the business of all the federal district courts. See Table II supra.

45. Table III supra confirms the data summarized in the Appendix infra. It is extraordimary that no reliable figures exist that break down the docket of the Suprante Court based on the court below. For some years the HARvard Law REview did this, $b$ it they stopped in 1962. The author is advised that the Clerk of the Supreme Court is now starting to couut cases in this mauner. For the October Term 1973, the percentage of state cases was 26.5 (1111 cases out of a total of 4178 ), which also confirms the data in the Appendix.

46. Now the 5000 series; formerly the Miscellaneous docket. 


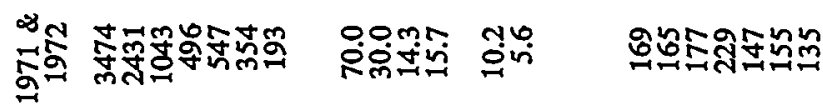

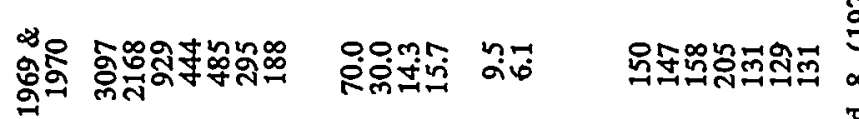

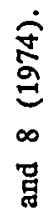

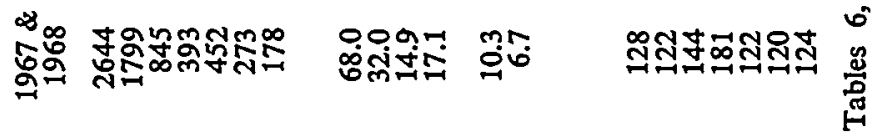

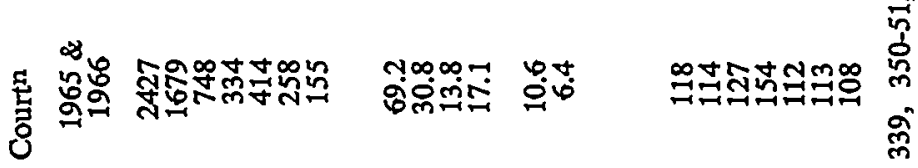

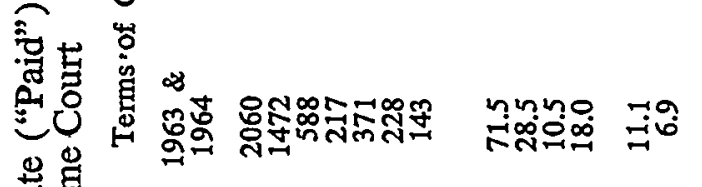

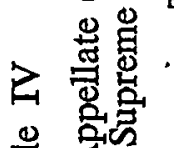

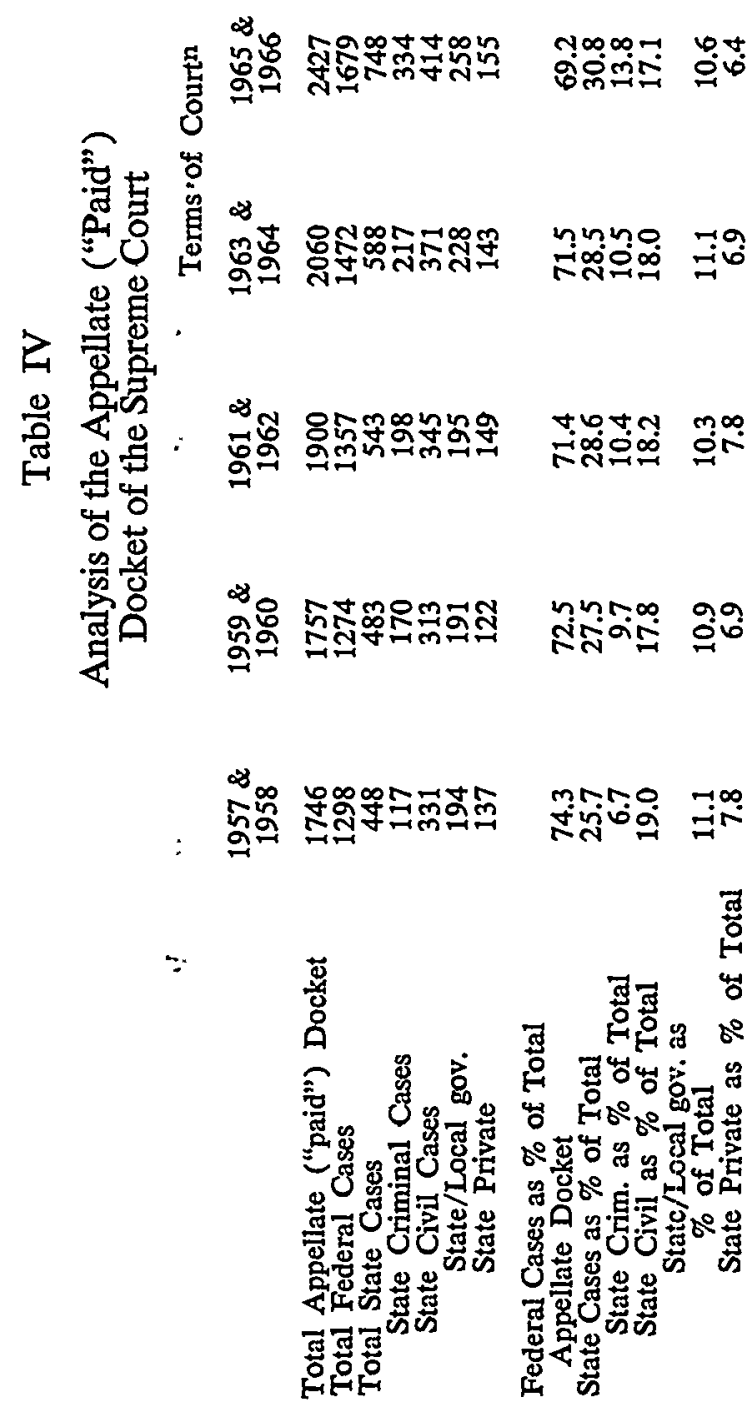

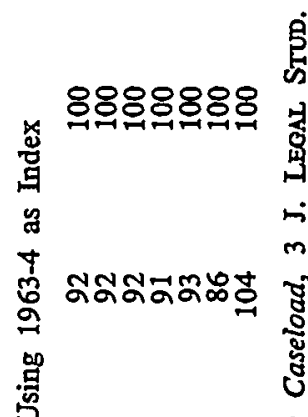

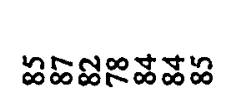
蒄

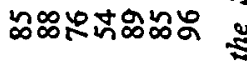

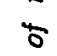
छั

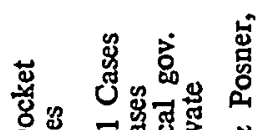

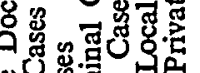

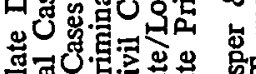

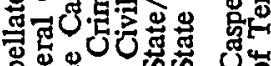
的

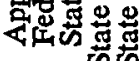

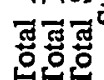




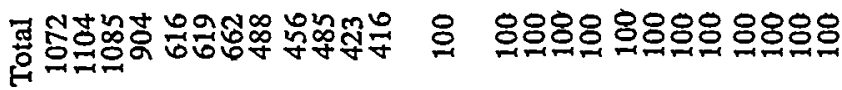

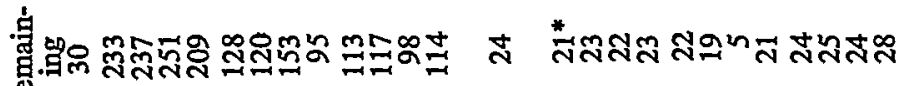
ณ

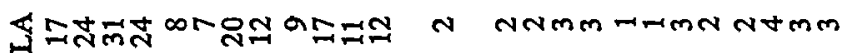

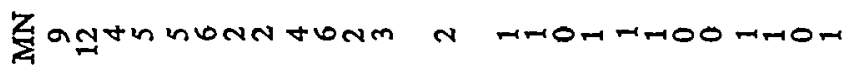

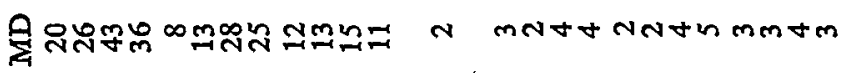

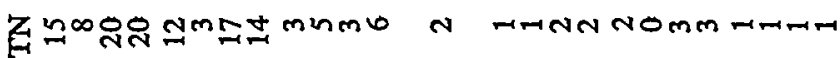

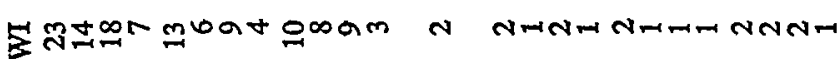

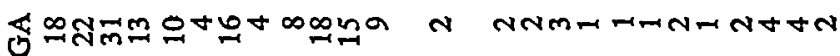

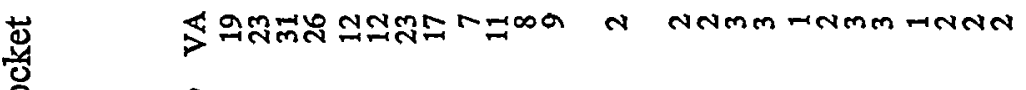

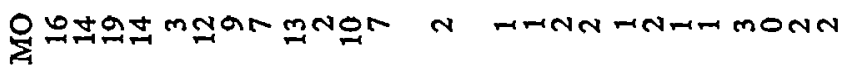

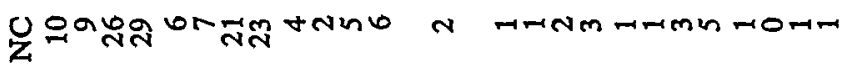

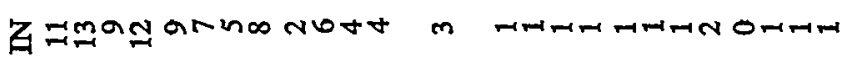

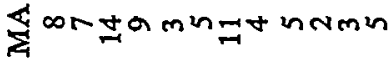

$m$ mmMOMNM HOMH

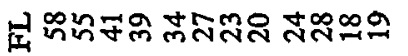

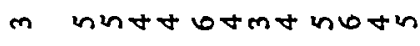

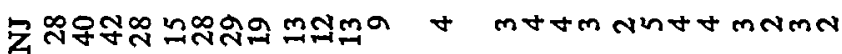

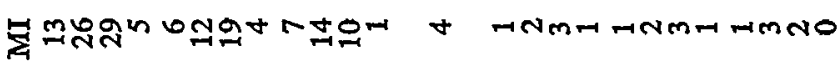

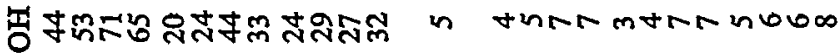

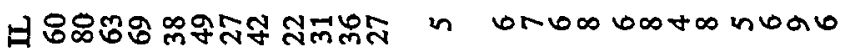

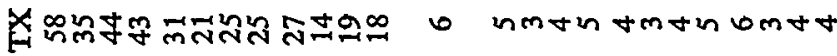

๔

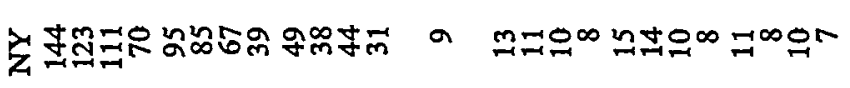

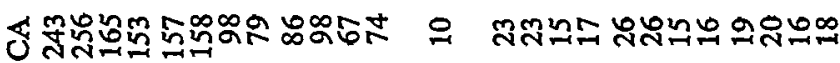

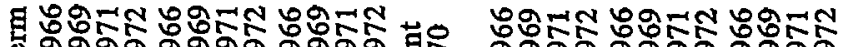

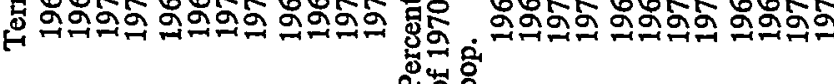

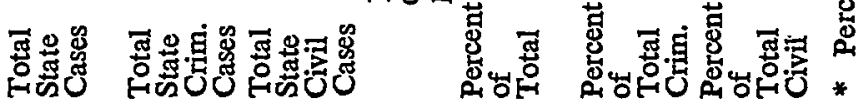


number of criminal cases. The obvious explanation for these divergences is that the size and composition of the in forma pauperis docket has been shifting in the opposite direction from the paid docket. One possible explanation for the increase in state criminal cases on the paid docket is that some of the people who formerly filed in propria persona are now paying the filing fee.

Further analysis of the data in the Appendix, however, makes the matter a good deal more mysterious. Table $\mathrm{V}$ shows what the courts of the 20 most populous states contributed to the total docket of the Supreme Court. Almost all of the decline noted above is attributable to two states, California and New York. Furthermore, there is a profound difference in the productivity of the various states. California and Florida produce Supreme Court litigation far in excess of their representation in the population; Pennsylvania, Michigan and Minnesota are even more dramatically underrepresented. No one has suggested a plausible explanation for this phenomenon. It does suggest the need for extreme caution in treating state courts as essentially fungible contributors to the Supreme Court's docket; there may well be as much difference between the various state courts as there is between the state and federal courts. Moreover, state courts can be moving in opposite direetions at the same time (for example, as California's contribution declines, Ohio's increases), so that generalization from total figures is very hazardous. The one generalization that seems safe is that shifts in the criminal docket are not the controlling element; a state productive of criminal cases will be about equally productive of civil cases.

Lacking figures that can be regarded as much more than suggestive, one is reduced to operating on unprovable but at least plausible assumptions. That the business of the state courts has grown over the last 10 to 15 years at a rate at least as rapid as that for the population would seem to be a conservative estimate simce the forms of legal regulation have increased faster than the population has grown. It would also seem conservative to suppose that the percentage of cases in the state courts presenting a potentially dispositive federal issue has at least. remaimed constant. If those two assumptions are accepted, it follows that the universe of cases that might reach the Supreme Court for decision has been growing although, especially in recent years, the number of state cases on the docket has not. ${ }^{47}$ The most probable explanation for this development is that lawyers are not filing cases with the Court because they recognize that the Court is so unlikely to hear the case that the effort is unprofitable. For the same reason it nay be true that lawyers are no longer shaping cases from the outset to present a dispositive federal issue.

47. See the Appendix infra. 
In any event, what is clear is that the Supreme Court is far less likely than it was 10 or 20 years ago to decide a case begun in the state courts. This situation is scarcely surprising given the steady and substantial increase in the volume of federal court cases appearing on the Court's docket. State court cases represented substantially inore than 40 percent of the Supreme Court's docket during most of the terms between 1950 and the early 1960 's; ${ }^{48}$ the proportion dropped below 40 percent at the end of the 1960's and in the most recent years (October terms 1972 and 1973) it fell to 26 percent. $^{49}$ Looking at full opinions by the Court, a comparable decline in cases begun in a state court can be observed, especially in civil cases. The effect is unmistakable: federal questions in state courts are being finally resolved by state courts. It is not possible today for the United States Supreme Court to maintain more than token supervision of the resolution of federal law questions by the state courts. ${ }^{\text {b0 }}$

\section{Responses to the Lack of Supreme Court Supervision}

The lack of effective supervision over state courts in their enforcement of federal law is much riskier than is the de facto final lawmaking power of the federal courts of appeals, which has also derived froin the increase in the Supreme Court's docket. Numerous intangible forces tend to make federal judges loyal to the influence as well as the command of the Supreme Court. ${ }^{51}$ For example, federal judges hold hifetime tenure, rotate among each other on panels, ${ }^{52}$ meet annu-

48. See Table III supra.

49. Id.

50. In an attempt to verify this statement, a questionnaire was sent to approximately 12 judges of the high courts of various states. The judges were selected because they had served at least a decade on an important state court. In general, most thought the assumptions stated in the preceding paragraph were plausible (although they had no statistical data to support that impression), but a few felt that their court was being inadequately supervised on federal questions by the United States Supreme Court. A number of the judges made the important point that their court was increasingly tending to make constitutional decisions turn on cognate provisions of the state constitution rather than on the federal constitution, thus cutting off federal review in those cases where the decision supported a claim of right under both the state and federal constitutions. To the extent that this is a new developinent it operates to reduce the need for federal appellate review of state court decisions. The questionnaire was sent out by the Commission on Revision of the Federal Court Appellate System; the results were explicitly made confidential and have not been published.

51. Cf. Byrd v. Blue Ridge Elec. Coop., Inc., 356 U.S. 525 (1958).

52. Intercircuit visiting is common, especially by senior circuit judges; also, district judges often sit on assignment at the court of appeals level. Current figures ineasuring the frequency of visiting judges are seemingly unavailable. Earlier data are available in Shafroth, Survey of the United States Courts of Appeals, 42 F.R.D. 243 (1967). Threejudge district courts, although their continuation in the statutes scems threatened, also serve to bring judges into contact with each other outside of their normal working pattern. 
ally at circuit conferences, and many serve on committees of the Judicial Conference. Furthermore, despite the recent increase in their number, there are still fewer than 100 authorized positions on the courts of appeals. ${ }^{53}$ In contrast, there is relatively little beyond the constitutionally required oath that binds the more than 200 state supreme court judges to the United States Supreine Court. ${ }^{.4}$ Most state judges do not have lifetime tenure and many unust rely on local political forces for continuation in office. Their professional contacts focus inward toward their own state court colleagues, although some organizations that bring judges of different states into contact have recently emerged. 55

If every decision of the United States Supreme Court were politically popular, this problem would not be so serious, but the reality is inevitably otherwise. At times political advantage can be obtained by resisting the Supreme Court, either with respect to a specific case or doctrine or through a generalized lashing-out at the Court. It is to the credit of the professionalism of state court: judges that they have so imfrequently indulged in insubordination, but one would be blind not to recognize their power to subvert, a power: enormously compounded in this context by the ease with which a result can be made to turn on some issue of state law rather than on the federal question that was presented.

The inability of the Supreme Court to review more than a handful of state court decisions presenting a federal question and the ease with which a federal issue can be protected from appellate review by a hostile state judiciary are, at least in part, responsible for the development of federal habeaus corpus for state prisoners. The story is long and complex and need not be developed here at length. ${ }^{56}$ It can be summarized somewhat pragmatically. Starting early in the 1950's and through at least the 1960's, the Supreme Court established standards of fair criminal procedure applicable to the states through the fourteenth amendment. The decisions were broadly applicable to many

53. There were 97 authorized court of appeals judgeships and 400 authorized district court judgeships in fiscal year 1972. There are always, of course, a few unfilled positions, but this is more than compensated for by senior judges who carry a substantial workload. Altogether, there were 652 federal judges on the rolls in fiscal year 1972 (presumably including active and retired Justices of the Supreme Court as well as judges on specialized courts such as the Court of Claims). ADMinistrative OFFice of THE United States Courts, ANNual Report of the Director of the Administrative OFFICE OF THE UNITED STATES Courts 1972, at 217.

54. U.S. CONST, art. VI.

55. See, e.g., The Council of State Governments, Proceedinos of the Twentieth Annual Meeting of the Conference of CFitef Justices (1968).

56. See generally HART \& WECHSLER 2d, supra note 5, at 1424-514. 
kinds of criminal cases; $;$ compliance was frequently expensive to local government and, if effected in some notorious cases, was likely to engage the emotions of a society already preoccupied with crime. Direct review by the Supreme Court of the criminal conviction in a state court was a tolerably effective mechanism for declaring new constitutional doctrine; but, for essentially two reasons, it would not do as a means for enforcing the new law on a sometimes reluctant state judiciary: (1) there were too many cases; and (2) it was too easy to hide rejection of the constitutional claim behind state procedural law.

Building slowly out of some questionable history, ${ }^{58}$ the Court evolved the current system of federal post-conviction review of state criminal convictions. Reduced to essentials, the system may be described as follows: a state prisoner who thinks his trial was infected with federal constitutional error may seek certiorari from his state conviction. $^{59}$ The Supreme Court will almost certainly deny the petition. If the prisoner presented the constitutional issue through the appellate courts of the state on direct review, ${ }^{\text {Bo }}$ he may proceed immediately to the federal district court on liabeas corpus. That court may, and in some circumstances must, ${ }^{61}$ afford him an evidentiary hearing on his constitutional claim. The fact, if such it be, that the state supreme court did not consider the prisoner's claim on direct review because of an intervening state procedural issue does not bar the federal district court from considering the claim. ${ }^{62}$ However the federal district court resolves the matter, the case may then be appealed to the appropriate court of appeals, and from there by certiorari to the Supreme Court. ${ }^{63}$

This system meets many of the problems created by the inability of the Supreme Court adequately to review state judgments. The problem of volume is handled by using federal district judges as a screen with power to upset a state criminal conviction. The problein of an adequate, mdependent ground of state law is circumvented through a doctrinal tour de force that somehow imvests a district court

57. Some decisions applied generally to criminal trials (e.g., the right to counsel). Others related only to specific kinds of evidence (e.g., confessions) or were applicable only to certain kinds of cases (e.g., cases involving the death penalty).

58. See Oaks, Legal History in the High Court-Habeas Corpus, 64 Mich. L. Rev, 451 (1966).

59. At one point an effort to seek certiorari was required, Darr v. Burford, 339 U.S. 200 (1950), but the Court removed that requirement in Fay v. Noia, 372 U.S. 391 (1963).

60. If he did not, he must first present that issue through such post-conviction procedures as state law provides. This requirement for the exhaustion of state remedies is now reflected in 28 U.S.C. $\$ 2254$ (1970).

61. Townsend v. Sain, 372 U.S. 293 (1963). Townsend has since been codified in 28 U.S.C. $\$ 2254$ (d) (1970).

62. Fay v. Noia, 372 U.S. 391, 399 (1963).

63. 28 U.S.C. $\$ \S 2253,1254(1)(1970)$. 
with more power than the Supreme Court would have on direct review. ${ }^{64}$ But the system has costs as well, costs that today strike many as exorbitant. ${ }^{65}$ In addition to creating intolerable delays in the finality of criminal convictions, it adds a substantial burden to the busmess of the inferior federal courts whose overcrowded dockets are already a cause for alarm.

This process reveals the essential truth of Hamilton's observation that the state and federal courts are parts of "ONE WHOLE" system. ${ }^{00}$ As the volume of busmess in the federal trial courts increases, the capacity of the Supreme Court to review state court judgments declines, and that renders less effective the Supreme Court's appellate review of state courts. The result of these developments is expansion of federal trial court jurisdiction to protect the federal interests involved, and that expansion leads to an increase in the workload of the inferior federal courts.

The Supreme Court is the only federal court whose jurisdiction has ever been significantly reduced. The Judges Act of $1925^{67}$ openly recognized the reality that the Justices' time and energy was a limited resource that had to be conserved if it was to be used effectively. ${ }^{68}$ It is being recognized that there are also limits on the growth of the lower federal courts; simply adding judges to handle an increased workload has costs that many think unacceptable. ${ }^{\circ \theta}$ One obvious way to deal with this problem is to reduce the jurisdiction of the district courts, in effect, by transferring part of the workload to the state courts. This proposal is not just borrowing from Peter to pay Paul because state court systems have always carried a much larger volume of cases than have the federal courts. Filings in the federal district courts in California, for example, are about 3.8 percent of the filings in the Califorma superior courts ${ }^{70}$ - and the superior court does not handle misdemeanors, parking offenses, or civil cases below $\$ 5,000$. Moving even half of the load of the federal courts to the state courts would not add

64. See HART \& WeCHSLER 2d, supra note 5, at 1482-87.

65. The collected literature and a useful empirical study of the effect on one district court can be found in Shapiro, Federal Habeas Corpus: A Study in Massachusetts, 87 HARv. L. REv. 321 (1973). Professor Shapiro's study suggests that the raw number of cases vastly overstates the workload, but it also indicates there are serious uniformity problems in using district judges to perform an essentially appellate role.

66. The Federalist No. 82 (A. Hamilton) (his capitals).

67. Act of Feb. 13, 1925, ch. 229, $\S \S 237-40,43$ Stat. 936.

68. See HART \& WeChSLER 2d, supra note 5 , at 41.

69. See THE COMMISSION RePORT, supra note 1 , at 2.

70. Compare Administrative Office of the United States Courts, AnNual

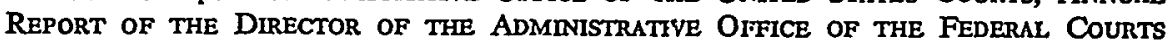
1973, at 122, 195, with Judiclal Council of Californis, Annunl Report of this Administrative Office of the California Courtis 185 (1973). 
significantly to the workload of the state courts-and, in any event, a shift of that dimension is not contemplated.

Most of the reform proposals that have been seriously pushed have involved removing from federal court jurisdiction (thus transferring to the state courts) inatters other than federal question litigation, most notably cases based upon diversity of citizenship. ${ }^{71}$ The implicit assumption, apparently, is that if a subject is important enough to be the object of congressional legislation it is automatically important enough to justify inclusion in the workload of the federal courts. Given the historical fact that state courts have always decided federal questions, it may be worth asking why it has been so easily assumed that federal rights must be triable in the first instance in federal trial courts. Probably this reflects a persistent doubt that state court judges can be trusted with power over matters that are, virtually by constitutional definition, of national concern. In the early days the chief concern was bias against out-of-staters; more recently, the concern lias been that state court judges lack sympathy for the substantive content of federal law.

Two meclianisms have been used as checks against uneven application of federal law by state court judges: (1) giving some described class of litigants the alternative or choice of trying their cause from the outset before a federal judge, $;^{72}$ or (2) providing for appellate review of the state court judgment by the Supreme Court. ${ }^{73}$ It sliould not be supposed that the two are equivalent; providing a federal trial forum is more protective of the federal interest and, though vastly more expensive, it is more effective in assuring the even-handed and uniform application of federal law. Appellate review by the Supreme Court is a weak substitute. It leaves the critical function of fact-determination largely in the hands of state court judges (or juries) whose supposed bias or predisposition is the cause for concern; it is only available to those litigants who can afford the expense of the full gamut of appeals; and it works only when the state court rests its decision on the federal question. Nonetheless, appellate review by the Supreme Court

71. The most elaborate, of course, was the ALI study, ALI, STUDY of THE DIVISION OF JURISDICTION BETwEen STATE AND Federal CourTs (1969) [hereinafter cited as ALI STUDY]. One of its major proposals, and probably its most controversial, was to restrict the diversity jurisdiction of the federal courts. That proposal would remit many cases for trial in the state courts but, unlike restrictions on federal qnestion jurisdiction, would not leave open the possibility of appeal to the Supreme Court if no federal question were presented. Judge Friendly's recent book, H. FrIENDLY, FEDERAL JURISDICTION: A GENERAL VIEW (1973), makes several proposals to meet the problems of the courts of appeals by restricting district court jurisdiction. In addition to eliminating diversity, he would remit seamen and railway workers to an administrative remedy.

72. See, e.g., 28 U.S.C. $\S \S 1441-51$ (1970).

73. 28 U.S.C. § 1257 (1970). 
was a meaningful check until recently because the Court was able to review the application of federal law by state courts in a systematic manner. Today, given the pressure on the Court's docket of cases from federal courts, there is no longer room for supervising the application of federal law in state courts except in an occasional and almost random manner. Thus, it is impossible to argue, as might have been done earlier, that discretionary appellate review by the Supreme Court will protect the federal interest in uniform application of federal law by state courts. If that be accepted, and the federal interest is genuine (as it must be for Congress to have acted), the pressure seems irresistible to maintain the present scope of federal trial court jurisdiction. Hence, those who would relieve the overload of the inferior federal courts by restricting district court jurisdiction are embarrassed by an mability to answer critics who see legitimate federal interests and doubt the willingness of state courts to recognize these interests in the absence of realistic supervision.

If this analysis is corrcct, the key to reform (or at least an important prerequisite) is the creation of federal appellate review of state court decisions in federal question cases which provides a real check. That cannot be done at the Supreme Court level because the Court lacks the capacity to handle such a load. But it would be possible to give a lower federal appellate court jurisdiction over state decisions, thereby reducing the pressure to maintaim and expand federal trial court jurisdiction. ${ }^{74}$ Appellate review by a fecleral court is a poor second to initial trial before a federal judge as a means for insuring the even-handed and uniform application of federal law. Continued reliance on full-scale trials before federal courts is an unrealistic alternative, however, because it would mevitably lead to pressures for a dramatic increase in the number of federal district court judges.

\section{III}

\section{The Advantages of Review of State Court Decisions by a New Federal ApPellate CourT}

However the structure of the federal appellate courts is reformed, the plan will be shaped principally by the needs of the federal courts. Thus, whether the existing circuits should be merged into a single court with multiple divisions or a new court created above the existing regional court of appeals is outside the scope of this Article. Nevertheless, it is proper to canvass the advantages and disadvantages of including appellate review of state courts withm the new system. Two advantages are obvious and, in substantial part, are the reciprocal of what

74. See text accompanying notes 58-66 supra. 
has already been discussed: (1) revision of collateral attack of state criminal convictions; and (2) flexibility in the distribution of business between state and federal courts. A third benefit, inore subtle and perhaps questionable, is the promotion of a more vigorous concept of federalism.

\section{A. Reform of Habeas Corpus}

Judge Haynsworth has proposed the creation of a new federal appellate court with power to review state criminal convictions for conformity with federal law, principally, of course, in the area of constitutional standards of due process. ${ }^{75}$ The Haynsworth plan is essentially identical to that proposed here: by making direct review meaningful, it should be possible to restrict the scope of collateral attack to those claims that could not have been presented on appeal. Since the Supreme Court cannot provide meaningful direct review, a new court with an obligatory jurisdiction would be inserted, with the Supreme Court retaining power to review cases heard by the new court in order to insure that doctrine remains consistent with the Court's conceptions. A new court-with new judges and jurisdiction-would be expensive, but there would be substantial benefits since the district courts and the courts of appeals would be relieved of nearly equivalent burdens on their dockets. Furthermore, matters would come to an end much sooner, a value of immense importance to the fair and possibly constructive administration of punishment.

Providing federal appellate review of state convictions would not solve all problems immediately, and is not without costs. It would continue and perhaps aggravate what some regard as an excessive preoccupation with procedural miceties and police regularity at the expense of concern for innocence or guilt. ${ }^{76}$ The doctrinal development of federal habeas corpus since Brown v. Allen ${ }^{77}$ has been complex, and statutory revision must be guided by the constitutional provision against suspension of the Great Writ. ${ }^{78}$ Nonetheless, obligatory federal appellate re-

75. Haynsworth, A New Court to Improve the Administration of Justice, 59 A.B.A.J. 841 (1973); Haynsworth, Improving the Handling of Criminal Cases in the Federal Appellate System, 59 CoRNell L. Rev. 597 (1974). An earlier proposal along similar lines was suggested by Mayers, Federal Review of State Convictions: The Need for Procedural Reappraisal, 34 GEO. WASH. L. REv. 615 (1966).

76. See Friendly, Is Innocence Irrelevant?, 38 U. CHI. L. REv. 142 (1970). Judge Friendly's title is more supportive of the statement in the text than the content of his article. There is, nonetheless, something odd about a system of post-conviction review that will not entertain what, to laymen, must seem the most powerful of all possible grounds: namely, that the conviction is wrong because the petitioner in fact committed no crime.

77. 344 U.S. 443 (1953).

78. U.S. Const. art. I, § 9. See HART \& WechsLER 2d, supra note 5, at 1510-14. 
view of state convictions would undoubtedly permit development of rules tending to foreclose repetitive petitions for habeas by applying doctrines analogous to res judicata to issues that were or might have been raised on direct review.

What is perhaps more important is that the law has changed since 1953 and Brown v. Allen. Because state defendants now have counsel at their trials, and because a lawyer and a transcript of the testimony are provided at public expense for purposes of appeal, the number of colorable claims of constitutional error that cannot be established (or refuted) by examination of the record should have fallen sharply. Thus, the need for an independent federal evidentiary hearing is now a relative rarity in most states. Moreover, many states provide a fully adequate post-conviction procedure to establish claims that can only be proved outside the record.

The adequate and independent state ground problem would remain troublesome; there is an unclear number of federal claims which cannot be reached on direct review but which are cognizable upon habeas corpus. ${ }^{79}$ The problem would be a majos: one for the new court, but one that might very well diminish over time as state courts became accustomed to more than an episodic review of their criminal decisions.

\section{B. Flexibility in the Reallocation of Business Between State and Federal Courts}

There are differing views as to whether the problems of the courts of appeals can be solved without a substantial restriction on the jurisdiction of the district courts. ${ }^{80}$ It is beyond the scope of this Article to enter into that debate. Clearly reduction of the federal question jurisdiction of the district courts will not come easily without a new level of appellate review of state court decisions. ${ }^{81}$ It may be useful to hist, without necessarily advocating, some possible reforins in order to illustrate the range of alternatives that a new level of appellate review might make politically acceptable.

Judge Friendly lias urged that FELA actions be taken out of the federal courts and that a workmen's compensation scherne be substituted. ${ }^{82}$ Much can be said both for and agamst a compensation scheme instead of tort recovery as a means of protecting against industrial acci-

79. Henry v. Williams, 299 F. Supp. 36 (N.D. Miss. 1969), seems to prove the existence of the gap. See generally HART \& WeCHSLER 2d, supra note 5, at 557-62.

80. Comparé Rosenberg, Planned Flexibility to Meet Changing Needs of the Federal Appellate System, 59 CORNELl L. REv. 576 (1974), with Friendly, Averting the Flood by Lessening the Flow, 59 CORNELL L. REv. 634 (1974).

81. See text accompanying notes 71-74 supra.

82. H. FRIENDLY, supra note 10 , at 129-31. 
dents. ${ }^{83}$ But it does not follow that if railroad unions are opposed to a compensation scheme they should be able to insist that their members be allowed to sue in the federal courts. FELA plaintiffs are now permitted to sue in state court, ${ }^{84}$ and no legal barrier stands in the way of making that state court jurisdiction exclusive. ${ }^{85}$ There is a good political argument against exclusive state jurisdiction, however, because state court enforcement may be uneven. No practical method exists by which the Supreme Court can effectively monitor all state courts via appellate review. ${ }^{86}$ This political argument would fall, or at least be greatly diminished, if a new federal court could and would review state court decisions in FELA actions.

FELA actions are obvious targets for reform because Congress has not only given state courts jurisdiction of suits under that act, but has also prohibited removal of such suits to the federal courts. ${ }^{87}$ Thus, if the plaintiff chooses a state court, the defendant is compelled to accept a state court trial. Making state court jurisdiction exclusive would limit the plaintiff's choice as the defendant's power is now limited. What is more important, however, is that the prohibition on removal demonstrates the weakness of the federal interest in FELA actions. There is no reason to suppose that state courts will be systematically biased in the trial of FELA actions that resemble routine personal injury trials in the state courts; and should any such bias exist, it can probably be corrected by appellate review.

There are other kinds of federal claims that might be shifted for trial to the state courts. The Fair Labor Standards Act authorizes suits in the state courts to recover danages for failure to pay the minimum wage. $^{88}$ Injunctive suits brought by the Secretary of Labor to conipel future coinphance may be brought only in the federal courts, ${ }^{89}$ but civil suits brought either by employees themselves or in the naine of the Secretary for their benefit may be brought in state courts. ${ }^{90}$ Why not make state court jurisdiction of damages actions exclusive? The inajor concern today is to insure that judgments in the state courts are correct

83. See Frank, Book Review, 59 A.B.A.J. 466 (1973).

84. 45 U.S.C. $\& 56$ (1948).

85. See Testa v. Katt, 330 U.S. 386 (1947).

86. This is the burden of Justice Frankfurter's dissent in Rogers v. Missouri Pacific R.R., 352 U.S. 500, 527 (1957); the Court's departure from that practice in that case, if such it was, evoked considerable protest. See HART \& WechSLER 2d, supra note 5, at 1625-29.

87. 28 U.S.C. $\S 144-5(a)(1970)$. The same argument can be made as to suits against common carriers under the Carmack Amendment, 49 U.S.C. $\$ 20(11)$ (1970), which also may not be removed if less than $\$ 3,000$ is involved. 28 U.S.C. $\$ 1445$ (b) (1970).

88. 29 U.S.C. $₹ 216(\mathrm{~b})(1970)$.

89. Id. at $\$ 217(1970)$.

90. Id. at \$ 216 (c) (1970). 
and uniform. That concern would largely be met by creation of an appellate review system that would reach and decide cases in which error was claimed. ${ }^{.1}$

A more radical suggestion would be to transfer some of the federal criminal load of the district courts to the states. The observation that much of the criminal jurisdiction of the federal courts is duphicative of the states is scarcely original, ${ }^{92}$ and one way to transfer the load of Dyer Act $^{93}$ cases, prosecution of crimes on federal enclaves, ${ }^{94}$ or bank robbery prosecutions would be to encourage by rule or otherwise the nonprosecution of soine of those cases by the United States Attorney. ${ }^{95}$ A transfer of federal criminal cases could be accomplished more directly by providing either by statute or at the discretion of the United States Attorney for federal prosecution of federal crimes in the state courts. Although the idea sounds strange, it is not unknown historically; since Testa v. Katt ${ }^{96}$ its constitutionality seems clear. ${ }^{97}$

There are serious arguments against each of these proposals. The point here is not to urge their adoption, but rather to encourage their consideration as viable policy alternatives. For the most part they are unacceptable today because of the absence of any realistic check on the uniform and fair application of federal law. As to any one of then appellate review might seem inadequate, so that the only satisfactory method of protecting. the federal interest involved remains initial trial before a federal judge. As to those for which appellate review would seem sufficient, lowever, if the change were made a substantial burden could be lifted from the workload of the niferior federal courts.

\section{Abstention}

\section{Toward a More Vigorous Federalism}

The abstention doctrine is inordinately complex. ${ }^{98}$ The essential

91. Appellate review from the state courts to the existing courts of appeals is, of course, a possibility today. The best argument against that plan is that those appellate courts are already overwhelmed.

92. See Schwartz, Federal Criminal Jurisdiction and Prosecutors Discretion, 13 LAW \& CoNTEMP. PRoB. 64 (1948).

93. 18 U.S.C. $\$ 2312$ (1970) (interstate auto theft).

94. Trial in state courts here is peculiarly attractive to the extent that the prosecution charges a crime under the Assimilative Crimes Act, 18 U.S.C. $\S 13$ (1970), because the law to be applied in those cases is state law.

95. See Schwartz, supra note 92. See also H. FriendLY, supra note 10, at 55-61.

96. 330 U.S. 386 (1947).

97. Note, Utilization of State Courts to Enforce Federal Penal and Criminal Statutes: Development in Judicial Federalism, 60 HaRv. L. REv. 966 (1947); see also HART \& WeCHSLER 2d, supra note 5, at 437-38. Note, however, that Testa v. Katt only dealt with what one might call a private claim for civil damages rather than criminal prosecution by a federal officer.

98. See HART \& WeCHSLER 2d, supra note 5, at 985-1050; ALI STUDY, supra note 71 , at $282-98$. 
idea, however, is simply that there are situations where it would be best if a lawsuit were tried first in the state courts. For example, often state law is unclear and a claim of unconstitutionality of a state statute depends on how the statute is interpreted. Unnecessary constitutional decisonmaking can be avoided by resolving the state issue in the state courts in such a way as to fimesse the constitutional issue altogether. Consequently, the inany interests involved in the concept of comity are promoted whenever a federal court abstains from decision in favor of a state court determination of the state law.

Unfortunately, certain problems inhere in the concept of abstention. For exainple, at the time the decision to abstain must be made, it is impossible to tell how the state court will respond. It is inescapably a dilatory maneuver (sometimes costing years of delay ${ }^{99}$ ) and it is questionable whether comity is proinoted if the Supreme Court ultimately reverses a state supreme court decision sustaining the constitutionahity of a statute. Indeed, tensions might well be less if a lower federal court invalidated the state statute in the first instance without ever engaging the attention and pride of the state court system. ${ }^{100}$

The abstention doctrine achieved a new level of complexity in England v. Louisiana State Board of Medical Examiners. ${ }^{101}$ That case began in a federal court, which invoked the abstention doctrine; ${ }^{102}$ the hitigation then moved over to the state courts where the state law was ultimately sustained by the Louisiana appellate courts. Rather than appeal that decision to the United States Supreme Court, the plaintiffs went back to the district court where they were met by the not implausible argument that the Louisiana decision was res judicata of their federal claim. The plaintiffs responded that they had been more or less required to present the constitutional claim to the state court in order to litigate the state issue. This argument was sufficient to preserve their right to proceed to trial in the federal court; the court explamed, however, that in the future parties inust reserve the right to relitigate in the federal court if they wish to do so. The court was explicit in its reasoning: Congress had given the parties the right to proceed before a federal court and abstention would be inconsistent with that entitlement if it ineant that the federal inatter was left for final decision in the state courts.

99. The ALI STUDY, supra note 71, collects some notable examples.

100. See Amsterdam, Criminal Prosecutions Affecting Federally Guaranteed Civil Rights: Federal Removal and Habeas Corpus Jurisdiction to Abort State Court Trial, 113 U. PA. L. Rev. 793 (1965).

101. 375 U.S. 411 (1964).

102. Initially a one-judge district court dismissed the action, but that decision was reversed by the court of appeals. 259 F.2d 626 (5th Cir. 1958). A three-judge district court then determined to abstain. 180 F. Supp. 121 (E.D. La. 1960). 
There are two aspects of the right to be heard by a federal judge: (1) the right to have a case tried before, and the facts found by, a federal judge; and (2) the right to have federal judges decide federal questions. Although appellate review by the Supreme Court theoretically satisfies the latter, its crowded docket prevents the Court from providing effective review. A new court with appellate jurisdiction over state court judgments would meet this problem insofar as abstention was confined to cases not involving critical problems of fact determination. Where the case presented only legal issues the parties could be remitted for trial before a state court, with review of the issues of law before a federal court on appellate review. Sensitive cases could thus be transferred to the state courts for trial (at least if the state courts provided a reasonably swift and adequate remedy ${ }^{103}$ ) without depriving the person relying on a federal claim of his right to have the case ultiinately decided by federal judges. There would, of course, remain the difficult problem of deciding at a very early stage whether appellate review sufficiently, protected the national interest or whether the factfinding power was sufficiently important to require trial as well as appellate review before a federal judge. This problem may not be too serious, however, because the kind of cases usually requiring abstention often do not turn upon findings of fact. ${ }^{104}$

Abstention is now a deeply troublesome procedure which is applied erratically. Justice Douglas apparently decided that its costs outweigh the occasional benefits. ${ }^{105}$ The drafters of the ALI proposal for reform thought it worth the effort to preserve ${ }^{106}$ and Judge Friendly, although differing with the ALI formulation, also thinks abstention has a role to play. ${ }^{107}$ Assuming that it does have a place in the federal system, the utility and rationality of abstention would be greatly enhanced by review of the state court decision by a federal appellate court. Simce ouly one state statute is normally involved in an abstention case, obligatory review by the Supreme Court seems too costly in terms of the displaeeinent of other potential cases on the Court's calendar. This cost could be reduced by providing for review by a new federal appellate court.

103. This is a part of the problem presented by Dombrowski v. Pfister, 380 U.S. 479 (1965).

104. ALI Study of the Division of Jurisdiction Between State and Federal CourTs $\$ 1371$, Comment at 211 (Tent. Draft No. 6, 1968); cf. Wechsler, Federal Jurisdiction and the Revision of the Judicial Code, 13 LAw \& Contrmp. Pros. 216, 22930 (1948).

105. See England v. Louisiana State Bd. of Medical Examiners, 375 U.S. 411, 423 (1964) (Douglas, J., concurring).

106. ALI STUDY, supra note 71, at 282.

107. H. FRIENDLX, supra note 10, at 94-96. 


\section{Federalism and the Protection of Federal Interests}

Concern over the use of state courts to administer federal law derives from an apprehension that some state courts will treat unsympathetically certain kinds of federal claims; civil rights and the rights of criminal defendants come first to mind. This Article has argued that a new court with the capacity to provide appellate review of state court decisions would better protect federal interests from hostile state judiciaries. The difficulty today is not with appellate review, but with the mability of the Supreme Court to decide more than a handful of cases. Thus, by providing the supervision now lacking, the creation of a new federal appellate court below the Supreme Court, with jurisdiction over state courts, will permit an enlarged role for state courts in the articulation of federal law.

There is, however, another aspect of using state courts for federal questions-in a sense the reciprocal of the churlish and narrow reading of federal law that many observers expect from state courts. Occasionally a state court will over-read Supreme Court precedents and invalidate state statutes or official action on federal grounds when the Supreme Court itself would not do so. By definition, no federal interest is damaged by such a decision, but it does needlessly restrict state power and thus danages the values inherent in a federalism which presupposes that state governments should be free to act as they wish within constitutional boundaries. When a state court draws those boundaries too narrowly it impinges upon the freedom of choice of co-ordinate branches of state government (typically the legislature); although the imjury may be regarded as self-inflicted, it is nonethless real.

This problem has not always been regarded as important. Until 1914 the Supreme Court had jurisdiction over state cases only where the claim of federal right had been denied by the state court. ${ }^{108} \mathrm{Su}-$ preme Court review had been meant simply to insure that federal interests were protected. The case that stimulated a change in this pohicy illustrates how Supreme Court review may be used to protect federalism rather than federal interests. In Ives v. South Buffalo Railway Co., ${ }^{109}$ the New York Court of Appeals held the first American workinen's compensation act unconstitutional under the fourtecnth amend-

108. See text accompanying note 28 supra.

109. 201 N.Y. 271, 94 N.E. 431 (1911). Subsequently, New York amended its constitution to eliminate the state due process ground of Ives. N.Y. CoNST. art. I, $\$ 18$ (McKinney 1969). See also Arizona Employers' Liability Cases, 250 U.S. 400 (1918), interpreted in Evans v. Berry, 262 N.Y. 61, 186 N.E. 203 (1933) (interpreted as vitiating much of the Ives rationale); Bauman v. Town of Irondequoit, 122 N.Y.S. 2d 47, 204 Misc. 494 (Sup. Ct. 1953). 
ment. ${ }^{110}$ There was good reason to suspect that the United States Supreme Court would not so hold, but there was then no way to bring the case to the Court. Of course, the Court could and did soon hear cases involving workmen's compensation statutes that had been sustained by the courts of other states. ${ }^{111}$ The $1914 \mathrm{Act}^{112}$ was designed to avoid this problem by empowering the Supreme Court to hear cases sustaining claims of federal right; thus, a state legislature would not be inhibited in experimentation by an erroneous view of what the federal constitution required.

A recent Oregon case, however, demonstrates that the 1914 Act did not ehminate the problem entirely. Lenrich Associates v. Heyda ${ }^{113}$ was an action by the owners of a shopping center to enjoin a group of Hare Krishna monks from proselytizing on the shopping center mall. The monks' defense asserted rights under both the Oregon Constitution and the fourteenth anendment. The trial court sustained the claim that their religious freedom was being impaired. Before the case was heard by the Oregon Supreme Court, the Umited States Supreme Court decided Lloyd Corp. $v$. Tanner, ${ }^{114}$ a case involving the distribution of handbills expressing opposition to the Vietnain war within the confines of another shopping center. The majority opinion in Lloyd is not a model of clarity. Although the opimion clearly holds that there is no first annendment right to handbill on subjects unrelated to the busmess of the shopping center, ${ }^{115}$ it also contains language indicating that the shopping center owners would be deprived of their constitutionally protected property interests if they did not have the power to prohibit handbilling. ${ }^{118}$

Three justices of the Oregon Supreme Court read Lloyd as holding that the shopping center owner had a constitutionally protected property right to prohibit leafletting. ${ }^{117}$ Accordingly, these justices refused to consider the monks' claim that they had a constitutional right under the Oregon Constitution to proselytize in the shopping center. ${ }^{118}$ Two justices thought that Lloyd only defimed the scope of the first amendment protection of handbilling, but they divided on the Oregon

110. The New York Court of Appeals also rested its decision on the New York Constitution which, as Professor Wright has pointed out, would have effectively prevented Supreme Court review even under the 1914 Act because it would have been an adequate and independent state ground for the decision. C. Wright, LAW OF FEDERAL COURTS $\$ 107$ (1970). See note 124 infra.

111. FRANKFURTER \& LANDIS, supra note 25 , at 190-98.

112. Act of Dec. 23, 1914, ch. 2, 38 Stat. 790.

113. 264 Ore. 122, 504 P.2d 112 (1972).

114. 407 U.S. 551 (1972).

115. Id. at 563-66.

116. Id. at $567-70$.

117. 264 Ore. at 122-29, 504 P.2d at 112-16 (plurality opinion by McAllister, J.).

118. Id. 
constitutional issue-one thinking that religious liberty was improperly impaired, ${ }^{119}$ the other that it was not. ${ }^{120}$ The other justice (one did not participate) was uncertain as to the meaning of Lloyd but was confident that the Oregon Constitution did not help the monks. ${ }^{121}$

Although Lloyd was correctly applied as to the first annendment issue, there is substantial reason to think that the Oregon court gave far too much weight to the property interest claim of the shopping center owners. Suppose that the plurality of the Oregon Supreme Court was wrong in its reading of Lloyd and that the Umited States Supreme Court would have liad no difficulty in sustaining a decision resting on the Oregon Constitution that protected the right of the Hare Krishna monks to sell tracts on private property used for public purposes. This would mean that a majority of the Oregon Court failed to reacli the state constitutional issue because it misperceived the reach of federal law. It seems unlikely that the Supreme Court would have taken the case had certiorari been sought. ${ }^{122}$ No federal interest as such was impaired by the Oregon Court's deeision; rather what was damaged was the lawmaking capacity of the Oregon Supreme Court. To be sure, it was a self-inflicted wound, but in comparable situations the United States Supreme Court lias souglit to protect the autonomy of state lawmaking imstitutions from even indirect and subtle forms of federal imterference. ${ }^{123}$ Although it is impossible to count the cases in which this kind of problem is presented, these cases undoubtedly do arise $e^{124}$ and they are mevitably being crowded out of possible con-

119. Id. at 135, 504 P.2d at 119 (O'Connell, C.J., dissenting).

120. Id. at 129, 504 P.2d at 116-18 (Denecke, J., specially concurring).

121. Id. at 135, 504 P.2d at 118-19 (Holman, J., concurring).

122. There is a more recent, almost precisely parallel California case, Diamond v. Bland, 11 Cal. 3d 331, 521 P.2d 460, 113 Cal. Rptr. 468 (1974), cert. denied, 419 U.S. 885 (1974). The fact that two state supreme courts misread Lloyd might induce the Supreme Court to take the case. Three members of the California Supreme Court thought the California Constitution protected the right of plaintiffs in that case to solicit signatures and distribute literature in a shopping center. Four members of the Court, however, reserved that question, believing themselves bound by Lloyd to respect what they perceived as the federally protected property interest of the shopping center owner.

123. In part, that is the concern behind Erie R.R. v. Tompkins, 304 U.S. 64 (1938). See HART \& WeChSLER 2d, supra note 5, at 694-708; C. WRIGHT, LAW OF FEDERAI CourTs $\$ 56(1970)$.

124. Such cases do not arise as often as might be supposed because of the restriction on the Supreme Court's jurisdiction to cases not resting on an independent and adequate state ground and the tendency of most states to construe their state constitutions as identical to the federal constitution. The Supreme Court lias recently led in developing constitutional rights-except for those states that continue to apply substantive due process restraints on economic regulation, a practice that the Supreme Court has (or at least had) abandoned. The recent turn, if such it be, away from the decisions of the Warren Court may lead to a resurgence of interest in state constitutional law, a generally moribund source of law. See generally Linde, Without "Due Process", 49 ORe. L. Rev. 125 (1970); Falk, The State Constitution: A More Than "Adequate" Nonfederal Ground, 61 CalrF. L. Rev. 273 (1973). 
sideration for review because of the pressure on the Supreme Court's docket. A new federal appellate court would not be so incapacitated and thus would be able to protect against over-broad interpretations of federal law that improperly inhibit legitimate lawmaking efforts by state legislatures and courts.

\section{IV}

\section{The Disadvantages of Review of State Courts by a New Federal Appellate Court \\ A. Increasing the Workload of Inferior Appellate Courts}

The current interest in reforming the structure of the federal appellate court system was stimulated by the swollen dockets of most of the courts of appeals and the growing conviction that their problems could no longer be inet by improveinents in inethodology or by the appointment of additional judges. Adding a jurisdiction that does not presently exist would seein only to make an already intolerable condition worse. This Article, however, is premised on the creation of a new court above the courts of appeals-a court with nationwide jurisdiction whose decisions would be binding on all inferior federal courts as well as on state tribunals. Such a court would hear only cases that had already passed through the screen of one appellate review. ${ }^{125}$ Its principal contribution to the federal system would be to assist the Supreme Court in resolving inter- and intra-circuit conflicts and in exercising its law-naking function by rehieving the Court of soine of its present supervisory burden. Giving an additional jurisdiction over state courts to a new court with such a inandate would be entirely consistent with the new court's purpose and would substantially aunehorate the workload of other inferior federal courts and the Supreme Court. For exainple, quick rehef would be realized when the burden of reviewing habeas corpus petitions in the district courts and courts of appeals was reduced by substitution of a system in which state convictions were directly reviewed by the new court. ${ }^{126}$ Habeas corpus would not go away altogether ${ }^{127}$ and there would remain the current rash of prisoner complaints under the Civil Rights Act, ${ }^{128}$ but the problem would be signifi-

125. The Rosenberg-Carrington plan contemplates a Central Division which, as to criminal cases, would engage in a "searching" reviev/ for possible errors of constitutional magnitude even if the parties did not raise those issues. Apparently the Central Division would not review on the merits civil cases from state courts, but would only make a recominendation to the Supreme Court as to whether certiorari should be granted. See note 6 supra.

126. See text accompanying notes 75-79 supra.

127. See text accompanying note 79 supra.

128. 42 U.S.C. $\S 1983(1970)$. State prisoners filed 218 civil rights petitions in federal district courts in 1966; by I973 the number had jumped to 4,174, an increase of 
cantly reduced. Further relief could be accomphished by shifting to the state courts some kinds of cases now heard by the district courts. ${ }^{129}$

The number of state cases raising a federal question is unknown, as is the number of federal question cases that go through the state appellate system; there seems to be no way of estimating the universe of potential cases. ${ }^{130}$ The Supreme Court's state court burden has been about 1,000 cases a year for the last decade, just over one-half of those being criminal cases.131 Presumably, the new court's workload would be somewhat larger than this, since the certainty of review that would accompany the new court's obligatory jurisdiction would probably encourage lawyers to appeal state court decisions that they otherwise would not (because a petition for certiorari or appeal is almost certain to be unsuccessful). Thus, it is most realistic to assume that the state court workload of the new court will be larger than the Supreme Court's present state court workload, though the magnitude of the increase cannot be estimated. ${ }^{132}$

What can be said with confidence is that the new court could readily adopt practices that would make its workload much less onerous than what is normally associated with appellate review. Unlike the courts of appeals, the new court would only take cases that had already been through an appellate process; to the extent that a state court correctly disposed of a federal issue the new court's opinion need say little more than that. Cases that rest on an adequate and independent state ground could also be disposed of summarily. The remainder would require a reasoned opinion, but only on federal issues; the new court's decisions in those cases should significantly assist the Supreme Court, at least to the extent that the new court correctly anticipates or interprets the Supreme Court's thinking.

A decision by the new court should be helpful to the Supreme Court in its effort to control its own docket. Unlike cases from the courts of appeals, cases from the state courts come within the Supreme

over 1,814 percent. Administrative OfFice of the United States CoURTs, AnNual

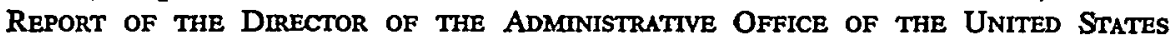
CourTs 1973, at 130 .

129. See text accompanying notes $82-97$ supra.

130. It would be hard to find even the total number of state cases since there are no national figures on the business of the state courts. So far as is known, no state attempts to count the number of cases in which a federal issue is presented and, short of elaborate sampling techniques, even estimation is impossible. Furthermore, the presence of a right of appeal to the new court inight stimulate the assertion of federal claims in state cases.

131. See the Appendix infra. In the October term of 1972 there were 904 cases from state courts filed in the Supreine Court of which 488 (or 53.8 percent) were criminal.

132. Indeed, to the extent that the decision whether to litigate is influenced by the availability of final federal review, one might expect an increase in the workload of state trial courts. 
Court's jurisdiction only to the extent that they present a federal issue. At present, however, no court below the Supreme Court has looked at the cases with that limitation im mind. The Court's decision whether to hear any particular case should be assisted by the fact that every case from a state court will have been reviewed and decided by the new federal court, whose judges will be as constrained as the Supreme Court is on which issues may be considered.

\section{B. Elongating the Appellate Process}

Every level of appeal imvolves costs; for the litigant, each level of appeal costs money and consumes time, and for the government, each level involves the expense of operating a court. Inserting a court above the state courts but below the Supreme Court adds a new level of appeal and potentially elongates the appellate process. This problein is much less severe with respect to state courts than it is with the courts of appeals, however, because the Supreme Court hears relatively few state court cases. Giving a new court appellate jurisdiction over state courts is rather more like restoring a level of appeal that used to exist than creating a new level.

This Article has argued that using state courts to decide federal questions is a necessary and useful procedure but the procedure is also dangerous without some form of supervision. Since the Supreme Court is mcapable, given its workload, of adequately perforining a supervisory function, ${ }^{133}$ a new court with appellate jurisdiction over state courts is necessary. Restoring federal review of federal questions decided by state courts is essential to a system that uses state courts to decide federal questions.

The cost to litigants in the new court should not be overwhelming. Only federal issues will be open, and they will ordinarily have been briefed once before. A brief is, of course, a more elaborate document than is a petition for certiorari or a jurisclictional statement; but to the extent that parties accept the decision of the new court and do not seek Supreme Court review, the cost of preparing papers for the Supreme Court will be saved.

Delay is a more serious problem. The new court will enable those who use the appellate process to postpone the mevitable to postpone it even further. Some relief would be provided if the Supreine Court shortened the time allowed for filing papers from the new court; also there should be no delay in transimitting the state record since it will already be on file with the new court. Nevertheless, establishing a new obligatory appellate review will permit those who wish to do so to ob-

133. See text accompanying notes $48-50$ supra. 
tain more delay than they presently can obtain by requesting discretionary review. The abuse of the appellate process for purposes of delay is scarcely unique to this proposal, however, and seems to be an imescapable concomitant of granting the right to appeal.

\section{Diminishing the Dignity of State Courts}

The proposal that state courts be given an enlarged responsibility in the administration of federal law ought to be understood as expressing confidence in the capabilities of the state judiciaries. Nonetheless, the judges of state supreme courts will doubtless resent being reversed by an "inferior" federal court rather more than they resent being reversed by the Supreme Court. To the extent that state court decisions are subject to review by judges shightly less lofty than Justices of the Supreme Court, the dignity of state courts will indeed suffer. Such a reduction will be minor, however, beeause the state supreme courts will remain the final and ultimate expositors of all inatters of state law which, despite the nationalization of the law in general, remains an extremely important area. Furthermore, to the extent that direct review of criminal cases is substituted for collateral attack via habeas corpus, there will be an increase in dignity since fewer state criminal convictions will be subject to reversal by a single federal district court judge.

\section{CONCLUSION}

The increasingly burdensome workload of the federal courts has led to a nuniber of major proposals for federal court reform. Appellate structures similar to those proposed by the Commission on Revision of the Federal Appellate Systein ${ }^{134}$ do not attack the entire problem, however, because they retain the basically discretionary nature of direct federal review of state court decisions which obtains today. ${ }^{135}$ If a new National Court of Appeals is established, it should be required to review all state court decisions concerning federal questions. Such a reform would facilitate the transfer of federal question cases to state courts, thus relieving the workload of the federal courts, while avoiding the danger of having state courts as de facto final deciders of federal questions, since the new court would provide meaningful federal appellate review. It would enable the judicial system to streamline the present system of post-conviction review, increase the ability of Congress to apportion work between the federal and state judicial systems, and enhance the contribution of the state courts to the developinent of federal law.

134. See text accompanying notes 2-4 supra.

135. See text accoinpanying notes 35-38 supra. 


\section{APPENDIX}

\section{SOURCE OF SUPREME COURT CASES}

$\begin{array}{lcccccc}\text { Term } & \text { DC } & \text { CA } & \text { State Ct. } & \text { O Fed } & \text { Total } & \text { \% State } \\ 1948 & 26 & 607 & 526(58) & 23 & 1182 & 44.5 \\ 1949 & 42 & 645 & 470(50) & 38 & 1195 & 39.3 \\ 1950 & 31 & 566 & 447(49) & 32 & 1076 & 41.5 \\ 1951 & 49 & 582 & 436(52) & 40 & 1107 & 39.4 \\ 1952 & 49 & 606 & 475(38) & 44 & 1174 & 40.5 \\ 1953 & 33 & 558 & 585(56) & 25 & 1201 & 48.7 \\ 1954 & 23 & 595 & 569(56) & 39 & 1226 & 46.4 \\ 1955 & 38 & 773 & 624(75) & 33 & 1468 & 42.5 \\ 1956 & 44 & 791 & 634(71) & 4.5 & 1514 & 41.9 \\ 1957 & 54 & 876 & 673(78) & 42 & 1645 & 40.9 \\ 1958 & 40 & 862 & 701(95) & 34 & 1637 & 42.8 \\ 1959 & 38 & 845 & 726(72) & 32 & 1641 & 44.2 \\ 1960 & 38 & 923 & 791(99) & 33 & 1785 & 44.3 \\ 1961 & 39 & 973 & 971(87) & 38 & 2021 & 48.0 \\ 1962 & 88 & 965 & 1069(96) & 39 & 2161 & 49.5 \\ 1966^{*} & 74 & 1450 & 1072(107) & 123 & 2719 & 39.4 \\ 1969 * & 121 & 1876 & 1102(114) & 23 & 3122 & 35.3 \\ 1971^{*} & 104 & 2254 & 1085(115) & 32 & 3475 & 31.2 \\ 1971^{* *} & 104 & 2239 & 967(114) & 32 & 3342 & 28.9 \\ 1972^{*} & 198 & 2335 & 904(144) & 24 & 3461 & 26.1\end{array}$

1. Statistics for 1948-1962 are taken from yearly notes "The Supreme Court-19 Term," in volumes 63 through 77 of the HaRvard LAW ReviEw. The totals represent all cases from inferior courts disposed of on the merits and on petition for certiorari. The figures in parentheses are the numbers of state cases brought by appeal and are included in the total figure given for the states each term. "O Fed" stands for other federal courts from which cases reach the Supreme Court Docket. The DC figure includes both three-judge and single-judge district court cases appealed directly to the Supreme Court.

* The figure for these years were compiled from The UNITEd STATEs Supreme COURT Journal by noting the source of each case, as its petition for certiorari or appeal was initially acted upon by the Court. The figures are therefore slightly out of synchronization with the figures for 1948-1962, based on final dispositions. This marginal difference results from the method of noting the cases in the Journal; it is equally representative of the coinposition of the docket as a break-down by final disposition.

** This is the composition of the 1971 docket without 133 cases-118 from state courts and 15 from the courts of appeal-summarily disposed of following the Court's determination that the death penalty, as presently administered, was violative of the Constitution. Many of these cases had been pending for several terms and their inclusion gives a soinewhat inflated picture of the caseloads normally flowing from the state courts. 


\section{STATE CASES SUPREME COURT DOCKET}

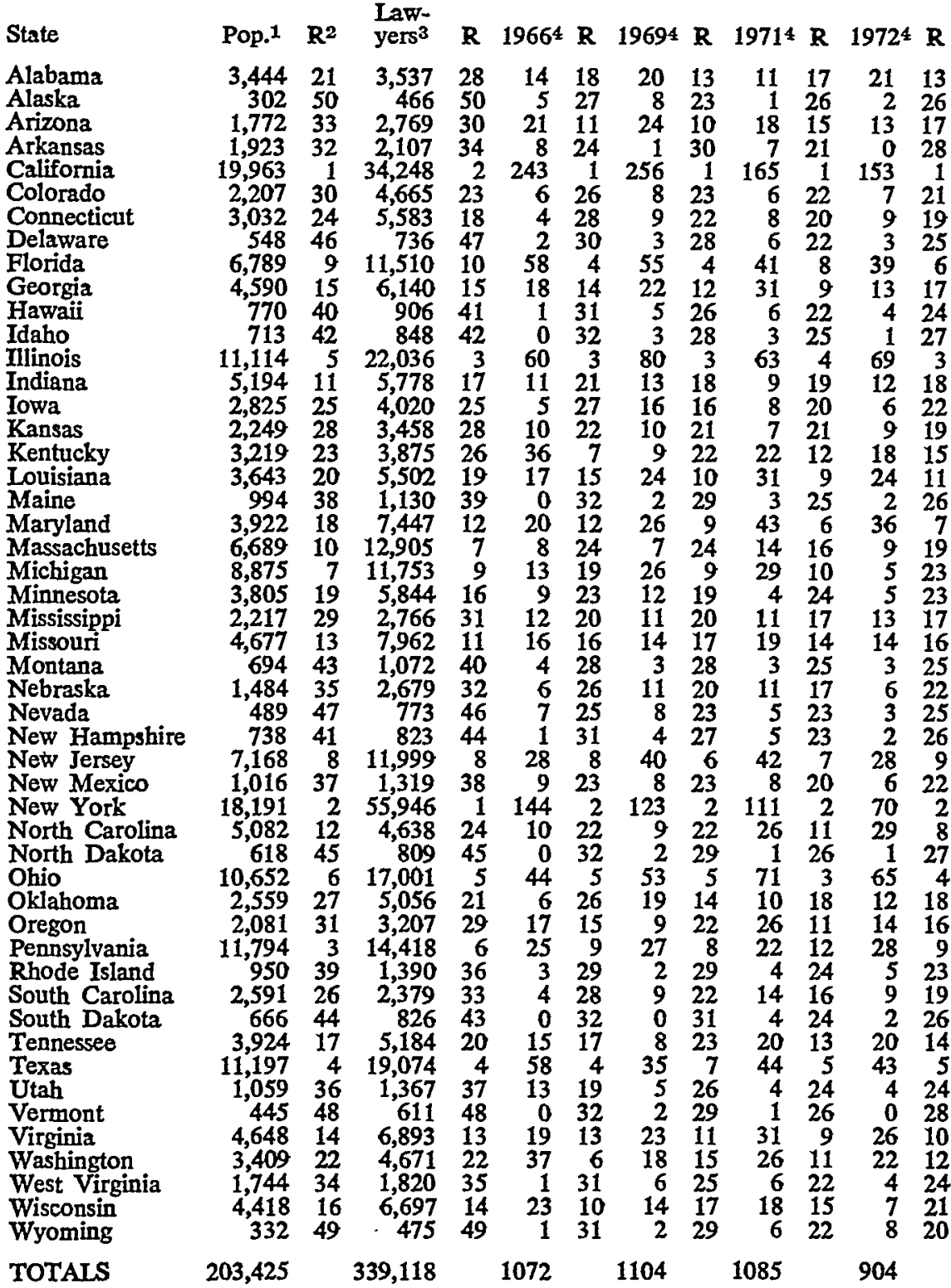

1. Population is given in thousands, and is based on the 1970 Decennial Census of the United States, as provided in AMERICAN BAR Foundation, THE 1971 LAwYER STATISTICAL REPORT, Table 10 at 26.

2. Rank.

3. American Bar Foundation, The 1971 Lawyer Statistical Report, Table 10 at 26.

4. These figures were conpiled from The UnITEd STATES SUPREME Court Journal by noting the source of each case, as listed when its application for certiorari or appeal was initially acted upon by the Court. They reflect only those cases in which direct review is sought by certiorari or appeal. 


\begin{tabular}{|c|c|c|c|c|}
\hline STATE CASES & SUPF & IE COURT & DOCKET & 1966 TERM \\
\hline STATE & CIVIL & CRIMINAL & TOTAL & RANK \\
\hline Alabama & 5 & 9 & 14 & 18 \\
\hline Alaska & 4 & 1 & 5 & 27 \\
\hline Arizona & 9 & 12 & 21 & 11 \\
\hline Arkansas & 2 & 6 & 8 & 24 \\
\hline California & 86 & 157 & 243 & 1 \\
\hline Colorado & 2 & 4 & 6 & 26 \\
\hline Connecticut & 3 & 1 & 4 & 28 \\
\hline Delaware & 1 & 1 & 2 & 30 \\
\hline Florida & 24 & 34 & 58 & 4 \\
\hline Georgia & 8 & 10 & 18 & 14 \\
\hline Hawaii & 1 & 0 & 1 & 31 \\
\hline Idaho & 0 & 0 & 0 & 32 \\
\hline Illinois & 22 & 38 & 60 & 3 \\
\hline Indiana & 2 & 9 & 11 & 21 \\
\hline Iowa & 4 & 1 & 5 & 27 \\
\hline Kansas & 5 & 5 & 10 & 22 \\
\hline Kentucky & 4 & 32 & 36 & 7 \\
\hline Louisiana & 9 & 8 & 17 & 15 \\
\hline Maine & $\mathbf{0}$ & $\mathbf{0}$ & $\mathbf{0}$ & 32 \\
\hline Maryland & 12 & 8 & 20 & 12 \\
\hline Massachusetts & 5 & 3 & 8 & 24 \\
\hline Michigan & 7 & 6 & 13 & 19 \\
\hline Minnesota & 4 & 5 & 9 & 23 \\
\hline Mississippi & 8 & 4 & 12 & 20 \\
\hline Missouri & 13 & 3 & 16 & 16 \\
\hline Montana & 2 & 2 & 4 & 28 \\
\hline Nebraska & 2 & 4 & 6 & 26 \\
\hline Nevada & 4 & 3 & 7 & 25 \\
\hline New Hampshire & $\mathbf{0}$ & 1 & 1 & 31 \\
\hline New Jersey & 13 & 15 & 28 & 8 \\
\hline New Mexico & 5 & 4 & 9 & 23 \\
\hline New York & 49 & 95 & 144 & 2 \\
\hline North Carolina & 4 & 6 & 10 & 22 \\
\hline North Dakota & $\mathbf{0}$ & 0 & 0 & 32 \\
\hline Ohio & 24 & 20 & 44 & 5 \\
\hline Oklahoma & 4 & 2 & 6 & 26 \\
\hline Oregon & 8 & 9 & 17 & 15 \\
\hline Pennsylvania & 14 & 11 & 25 & 9 \\
\hline Rhode Island & 3 & 0 & 3 & 29 \\
\hline South Carolina & 3 & 1 & 4 & 28 \\
\hline South Dakota & $\mathbf{0}$ & $\mathbf{0}$ & $\mathbf{0}$ & 32 \\
\hline Tennessee & 3 & 12 & 15 & 17 \\
\hline Texas & 27 & 31 & 58 & 4 \\
\hline Utah & 5 & 8 & 13 & 19 \\
\hline Vermont & $\mathbf{0}$ & 0 & 0 & 32 \\
\hline Virginia & 7 & 12 & 19 & 13 \\
\hline Washington & 27 & 10 & 37 & 6 \\
\hline West Virginia & 1 & 0 & 1 & 31 \\
\hline Wisconsin & 10 & 13 & 23 & 10 \\
\hline Wyoming & 1 & 0 & 1 & 31 \\
\hline TOTAL & $\begin{array}{l}456 \\
42.5 \%\end{array}$ & $\begin{array}{l}616 \\
57.5 \%\end{array}$ & 1072 & \\
\hline
\end{tabular}

Compiled from The United States Supreme Court Journal, 1966 Term. 
STATE CASES SUPREME COURT DOCKET 1969 TERM

\section{STATE}

Alabama

Alaska

Arizona

Arkansas

California

Colorado

Connecticut

Delaware

Florida

Georgia

Hawaii

Idaho

Illinois

Indiana

Iowa

Kansas

Kentucky

Louisiana

Maine

Maryland

Massachusetts

Michigan

Minnesota

Mississippi

Missouri

Montana

Nebraska

Nevada

New Hampshire

New Jersey

New Mexico

New York

North Carolina

North Dakota

Ohio

Oklahoma

Oregon

Pennsylvaına

Rhode Island

South Carolina

South Dakota

Tennessee

Texas

Utah

Vermont

Virginia

Washington

West Virginia

Wisconsin

Wyoming

TOTAL

\section{OIVIL}

11

1

7

0
98

7

5

3

28

18

3

3

31

6

10

3

5

17

1

13

2

14

6

4

2

2

3

5

1

12

3

38

2

2

29

2

8

14

2

2

0

5

14

4

2

11

11

5

8

2

485

$43.9 \%$
CRIMINAL

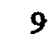

7

17

1

158

1

4

0

27

4

2

0

49

7

6

7

4

7

1

13

5

12

6

7

12

1

8

3

3

28

5

85

7

0

24

17

1

13

0

7

0

3

21

1

0

12

7

1

6

0

619

$56.1 \%$
TOTAL RANK

$20 \quad 13$

823

$24 \quad 10$

130

1

823

922

$3 \quad$. 28

$55 \quad 4$

$\begin{array}{rr}22 & 12 \\ 5 & 26\end{array}$

$\begin{array}{ll}5 & 26 \\ 3 & 28\end{array}$

$80 \quad 3$

$13 \quad 18$

1616

$10 \quad 21$

922

$24 \quad 10$

229

269

$7 \quad 24$

269

1219

1120

$14 \quad 17$

328

1120

823

427

$40 \quad 6$

823

922

$2 \quad 29$

53

$19 \quad 14$

922

278

$2 \quad 29$

922

$0 \quad 31$

823

$35 \quad 7$

526

229

$23 \quad 11$

$18 \quad 15$

625

$14 \quad 17$

$2 \quad 29$

1104

Compiled from The UNTred STATES SuPReMe COURT Journal, 1969 TERM. 
[Vol. 64:943

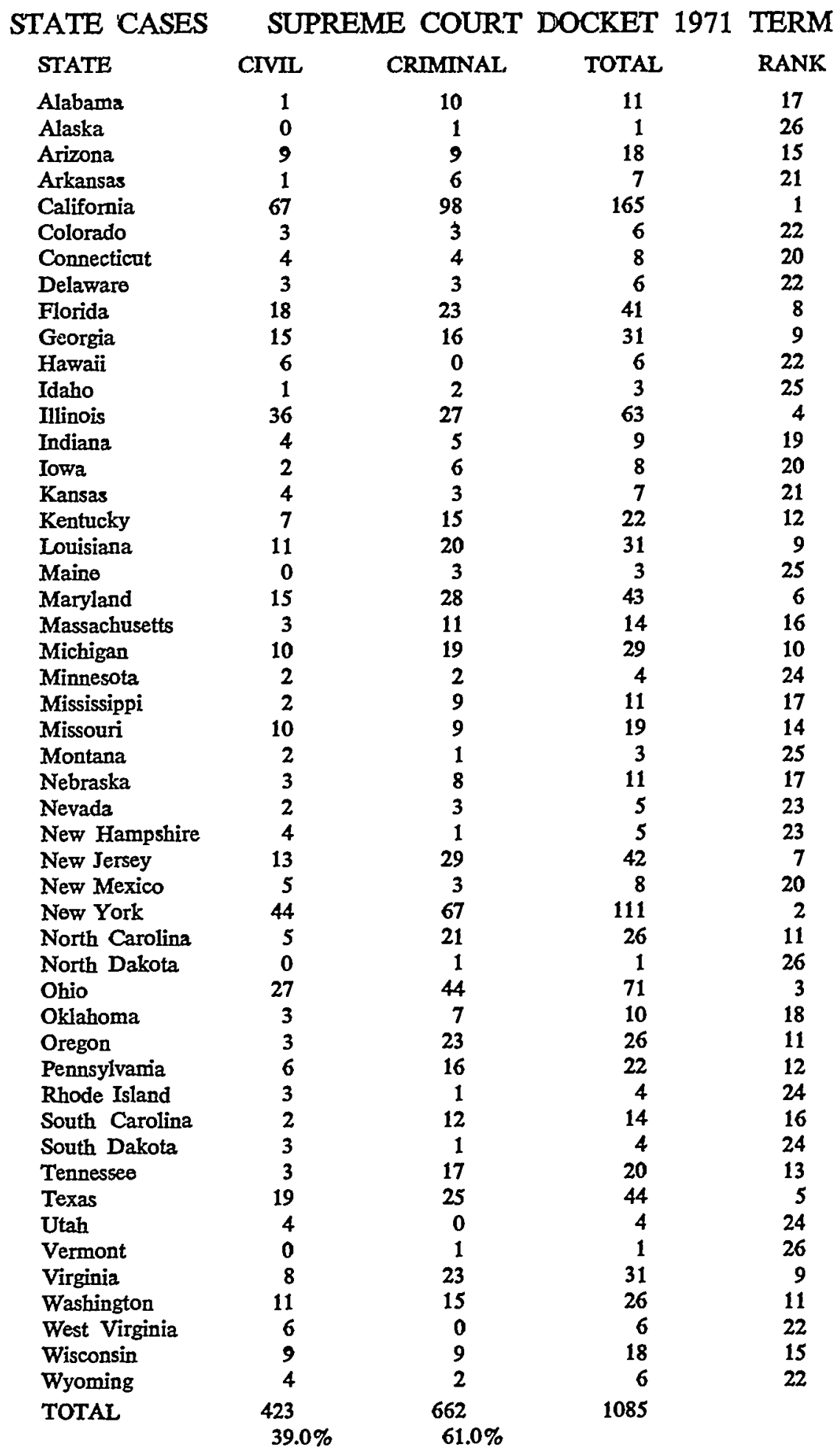

Compiled from The United States Supreme Court Journat, 1971 Term. 
STATE CASES SUPREME COURT DOCKET 1972 TERM

STATE

Alabama

Alaska

Arizona

Arkansas

Califomia

Colorado

Connecticut

Delaware

Florida

Georgia

Hawaii

Idaho

Illinois

Indiana

Iowa

Kansas

Kentucky

Louisiana

Maine

Maryland

Massachusetts

Michigan

Minnesota

Mississippi

Missouri

Montana

Nebraska

Nevada

New Hampshire

New Jersey

New Mexico

New York

North Carolina

North Dakota

Ohio

Oklahoma

Oregon

Pennsylvania

Rhode Island

South Carolina

South Dakota

Tennessee

Texas

Utah

Vermont

Virgima

Washington

West Virginia

Wisconsin

Wyoming

TOTAL

\section{CIVIL}

\section{4}

1

8

0

74

5

6

1

19

9

2

1

27

\section{4}

1

5

10

12

1

11

5

1

3

3

7

\section{3}

4

3

2

9

3

31

6

1

32

4

9

16

5

5

0

6

18

4

0

9

17

2

3

4

416

$46.0 \%$

\section{CRIMINAL}

17

1

5

0

79

2

3

2

20

4

2

42

8

5

4
8

12

1

25

4

4

2

10

7

0

2

0

0

19

39

23

0

33

8

5

12

0

4

2

14

25

0

0

17

5

2

4

4

488

$54.0 \%$
TOTAL RANK

$21 \quad 13$

226

$13 \quad 17$

$0 \quad 28$

$153 \quad 1$

$7 \quad 21$

$9 \quad 19$

325

$39 \quad 6$

$13 \quad 17$

424

127

$69 \quad 3$

1218

622

$9 \quad-19$

$18 \quad 15$

$24 \quad 11$

226

$36 \quad 7$

$9 \quad 19$

523

$5 \quad 23$

$13 \quad 17$

$14 \quad 16$

325

622

325

226

289

622

$70 \quad 2$

$\begin{array}{ll}29 & 8\end{array}$

127

$65 \quad 4$

$12 \quad 18$

$14 \quad 16$

289

523

$9 \quad 19$

226

$20 \quad 14$

4355

424

$0 \quad 28$

2610

$22 \quad 12$

424

721

820

904

Compiled from The UNIEd States SUTreme COURT Joural, 1972 Term. 